\title{
New Perspective on Performances and Limits of Solar Fresh Air Cooling in Different Climatic Conditions
}

\author{
Ancuta C. Abrudan ${ }^{1}$, Octavian G. Pop ${ }^{2}$, Alexandru Serban ${ }^{3}$ and Mugur C. Balan ${ }^{2, *}$ \\ 1 Department of Building Services, Technical University of Cluj-Napoca, Bd. 21 Decembrie 1989 128-130, \\ 400604 Cluj-Napoca, Romania; ancuta.abrudan@insta.utcluj.ro \\ 2 Department of Mechanical Engineering, Technical University of Cluj-Napoca, Bd. Muncii 103-105, \\ 400461 Cluj-Napoca, Romania; octavian.pop@termo.utcluj.ro \\ 3 Department of Thermal Engineering, University Politehnica of Bucharest, Splaiul Independentei, 313, \\ 060042 Bucharest, Romania; alexandru.serban@criomecsa.ro \\ * Correspondence: mugur.balan@termo.utcluj.ro
}

Received: 8 April 2019; Accepted: 31 May 2019; Published: 2 June 2019

\begin{abstract}
The study carried out by simulation, concerns the thermal behavior of an office building's solar fresh air cooling system, based on a $\mathrm{LiBr}-\mathrm{H}_{2} \mathrm{O}$ absorption chiller in different climatic conditions. The coefficient of performance (COP) and the solar fraction were considered performance parameters and were analyzed with respect to the operating limits-the risk of crystallization and maintaining at least a minimum degassing zone. A new correlation between the required solar hot temperature and the cooling water temperature was established and then embedded in another new correlation between the COP and the cooling water temperature that was used in simulations during the whole cooling season corresponding to each location. It was found that-the solar hot water should be maintained in the range of $(80-100){ }^{\circ} \mathrm{C}$ depending on the cooling water temperature, the COP of the solar $\mathrm{LiBr}-\mathrm{H}_{2} \mathrm{O}$ absorption chiller with or without cold storage tank could reach (76.5-82.4)\% depending on the location, and the solar fraction could reach (29.5-62.0)\% without cold storage tank and could exceed $100 \%$ with cold storage tank, and the excess cooling power being available to cover other types of cooling loads-through the building envelope, from lighting, and from occupants, etc.
\end{abstract}

Keywords: solar cooling; absorption chiller; $\mathrm{LiBr}-\mathrm{H}_{2} \mathrm{O}$; operating conditions; climatic conditions

\section{Introduction}

The building sector accounts for $40 \%$ of the global energy consumption [1] and heating ventilation and air conditioning (HVAC) is one of the major energy consumers in buildings [2]. Additionally, global warming is expected to cause more overheating in buildings [3].

Since solar radiation is a major component of the cooling load, there is also a challenge to convert solar radiation into useful forms of energy [4]. Solar radiation directly influences the cooling load of buildings, thus the two are correlated at least to a certain extent [5].

Under these circumstances, solar cooling systems and particularly solar fresh air cooling systems (SFACS) have been a major research topic in the last few years. Between several other solar cooling technologies, the solar absorption cooling systems (SACS) were found to be the most energy efficient for six major cities in Australia [6]. SACS are considered a sustainable solution for solar driven air conditioning equipment, particularly in warmer climates, even though some problems related to these systems still exist $[7,8]$. Based on the coefficient of performance (COP), SACS are more efficient than other systems, such as the adsorption ones [9].

Between several working agents, the $\mathrm{LiBr}-\mathrm{H}_{2} \mathrm{O}$ solution is considered one of the most preferable options because it can provide the best annual performance [9], it is ecofriendly because water is used as the refrigerant, and it provides an excellent cooling potential due to the high latent heat of water [10]. 
The most widespread version of $\mathrm{LiBr}-\mathrm{H}_{2} \mathrm{O}$ SACS is the single effect one and several studies have been dedicated to this type of equipment by experiment $[4,11]$ or by modelling $[12,13]$.

Even though air cooling is considered in several studies, all the $\mathrm{LiBr}-\mathrm{H}_{2} \mathrm{O}$ absorption chillers that are currently on the market are water-cooled [14] and only a single model of an air-cooled single effect $\mathrm{LiBr}-\mathrm{H}_{2} \mathrm{O}$ absorption chiller has ever been marketed and was only available from 2005 to 2008 [14].

One of the main reasons why the expansion of air cooled $\mathrm{LiBr}-\mathrm{H}_{2} \mathrm{O}$ was limited is the crystallization risk under ambient conditions [15]. This problem also occurs with water-cooled $\mathrm{LiBr}-\mathrm{H}_{2} \mathrm{O}$ absorption systems, because $\mathrm{LiBr}$ is a salt with a crystalline structure and will crystallize at any concentration below a certain temperature [16]. This concern is a major operating issue of these systems. The possibility of avoiding the crystallization problem was investigated in some studies including $[8,17]$. Despite these concerns, recommendations related to the accepted operating conditions capable of avoiding crystallization in solar $\mathrm{LiBr}-\mathrm{H}_{2} \mathrm{O}$ SACS are not easily available in literature.

Another operating problem of SACS is providing a minimum concentrations difference between the diluted and the concentrated solution, named the degassing zone. This parameter is important because the solutions flow rates depend on the degassing zone, and low values of degassing zone determines high solutions flow rates $[7,10,13]$. Despite the dependence between the degassing zone and the solutions flow rates for the $\mathrm{LiBr}-\mathrm{H}_{2} \mathrm{O}$, recommendations for the minimum acceptable degassing zone are not available in literature.

The SACS can be driven by hot water with a relatively low temperature that can be provided by the common flat or evacuated tubes solar thermal collectors $[6,9]$. Concentrating solar collectors are also used in some solar cooling studies [5,13].

In order to provide more constant cooling power, several SACS are equipped with hot water storage tanks, but in some cases, cold water storage is preferred because of lower losses [4].

The goal of this study is to provide both the performances and limits of water cooled $\mathrm{LiBr}-\mathrm{H}_{2} \mathrm{O}$ SACS in different operating conditions. The COP of the absorption system and the solar fraction were evaluated as the efficiency parameters. A new correlation between the required solar hot temperature and the cooling water temperature was established and then embedded in the new correlation between the COP and the cooling water temperature. This correlation was used in simulations during the whole cooling season corresponding to each location. The risk of crystallization and the minimum degassing zone were considered the limitations from an operating conditions' point of view. The study continues from previous investigations related to the energy efficiency in buildings-the use of phase change materials in fresh air cooling systems [18]; evaluation of performances and limits of solar driven absorption chillers [17]; presentation of long term experimental study of a geothermal heat pump [19]; or evaluation of indirect evaporative cooling performances [20].

\section{Materials and Methods}

\subsection{Characteristics of the Building and Climatic Conditions}

The office building that was completely characterized and previously investigated in [18] was also considered in this study, situated in different locations worldwide to evaluate the influence of climatic conditions on the solar cooling system.

A 3D drawing of the building with solar thermal collectors placed on the roof is presented in Figure 1. 


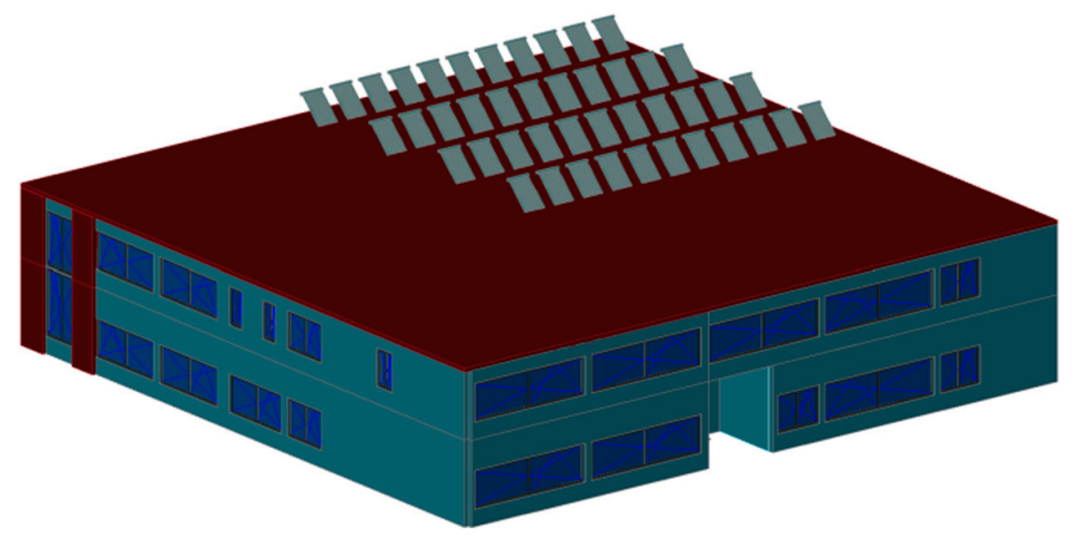

Figure 1. The 3D drawing of the building equipped with solar thermal collectors.

The solar thermal collectors are oriented to the South.

The climatic characteristics of the locations considered in this study, according to the Köppen-Geiger classification, are presented in Table 1.

Table 1. Climatic characteristics of the locations.

\begin{tabular}{cccccccc}
\hline Location & Country & Latitude $\left(^{\circ}\right)$ & Longitude $\left(^{\circ}\right)$ & Altitude (m) & $\begin{array}{c}\text { Time Zone } \\
\text { (hours) }\end{array}$ & $\begin{array}{c}\text { Climate } \\
\text { Classification }\end{array}$ & Climate Description \\
\hline Berlin & DEU & $52.517 \mathrm{~N}$ & $13.389 \mathrm{E}$ & 44 & 1 & Dfb & Warm humid continental climate \\
Paris & FRA & $48.857 \mathrm{~N}$ & $2.351 \mathrm{E}$ & 30 & 1 & Cfb & Oceanic climate \\
Monaco & FRA & $43.731 \mathrm{~N}$ & $7.420 \mathrm{E}$ & 2 & 1 & Csa & Hot-summer Mediterranean climate \\
Rome & ITA & $41.893 \mathrm{~N}$ & $12.483 \mathrm{E}$ & 42 & 1 & Csa & Hot-summer Mediterranean climate \\
Seville & ESP & $37.094 \mathrm{~N}$ & $2.358 \mathrm{E}$ & 499 & 1 & Csa & Hot-summer Mediterranean climate \\
Cairo & EGY & $30.049 \mathrm{~N}$ & $31.244 \mathrm{E}$ & 41 & 2 & BWh & Hot desert climate \\
Phoenix & USA & $33.450 \mathrm{~N}$ & $111.983 \mathrm{~W}$ & 337 & -7 & BWh & Hot desert climate \\
Las Vegas & USA & $30.083 \mathrm{~N}$ & $115.15 \mathrm{~W}$ & 648 & -8 & BWk & Tropical and subtropical desert climate \\
\hline
\end{tabular}

The climatic data for each location was based on the available typical meteorological year (TMY). The use of the TMY data is typical for several studies related to the energy efficiency in buildings like [21,22]. The TMY presents hourly based variations of several climatic parameters like-the global solar radiation on the horizontal plane $\left(\mathrm{I}\left(\mathrm{W} / \mathrm{m}^{2}\right)\right)$, the ambient (or dry bulb) temperature $\left(\mathrm{t}_{\mathrm{db}}\left({ }^{\circ} \mathrm{C}\right)\right.$ ), the direct $\left(\mathrm{I}_{\mathrm{dir}}\left(\mathrm{W} / \mathrm{m}^{2}\right)\right)$ and diffuse $\left(\mathrm{I}_{\text {dif }}\left(\mathrm{W} / \mathrm{m}^{2}\right)\right)$ solar radiation on the horizontal plane, the relative humidity of air $(\varphi(\%))$, and the wet bulb temperature $\left(t_{\mathrm{wb}}\left({ }^{\circ} \mathrm{C}\right)\right)$ etc.

The variations of the input data and of the calculated values of different parameters were presented for only two representative locations corresponding to the minimum and maximum values of different TMY based criteria as presented in Table 2.

Table 2. Locations with minimum and maximum values of climatic parameters.

\begin{tabular}{ccc}
\hline TMY Based Criteria & Min & Max \\
\hline Total yearly global solar radiation on horizontal plane & Berlin & Cairo \\
Maximum dry bulb temperature & Monaco & Las Vegas, Phoenix \\
Maximum wet bulb temperature & Berlin & Phoenix \\
\hline
\end{tabular}

Since there were five locations that reached at least one minimum or maximum value for one of the three climatic criteria (Berlin, Monaco, Cairo, Las Vegas, and Phoenix), Berlin was selected with two minimum values and Phoenix was selected with two maximum values. All of the data variations were represented only for the two selected locations.

The yearly variation of the global solar radiation on the horizontal plane and of ambient temperature for the locations of Berlin and Phoenix are presented in Figure 2. 


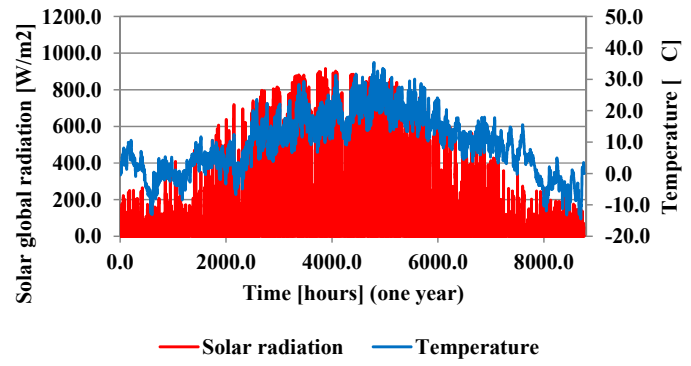

(a) Berlin

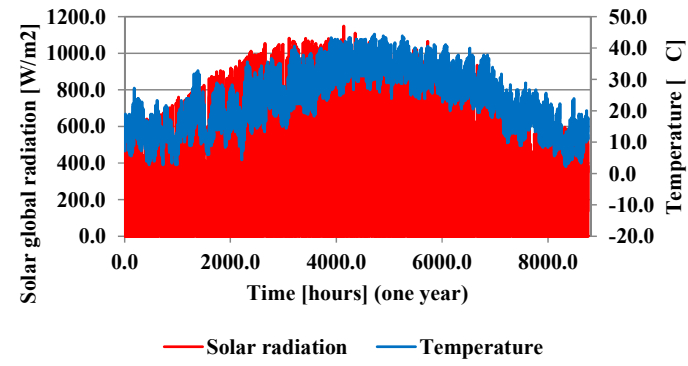

(b) Phoenix

Figure 2. Global solar radiation on horizontal plane and ambient temperature.

The following data relevant to the HVAC studies, corresponding to each location, are presented in Table 3-the total yearly global solar radiation on the horizontal plane, the maximum ambient temperature, and the maximum wet bulb temperature.

Table 3. TMY based data characteristics for each location.

\begin{tabular}{cccc}
\hline Location & $\begin{array}{c}\text { Total Yearly Global Solar Radiation on } \\
\text { Horizontal Plane } \\
\left(\mathbf{k W h} / \mathbf{m}^{\mathbf{2}} / \text { year) }\right.\end{array}$ & $\begin{array}{c}\text { Maximum Dry Bulb } \\
\text { Temperature }\left({ }^{\circ} \mathbf{C}\right)\end{array}$ & $\begin{array}{c}\text { Maximum Wet Bulb } \\
\text { Temperature }\left({ }^{\circ} \mathbf{C}\right)\end{array}$ \\
\hline Berlin & 1077 & 35.4 & 23.6 \\
Paris & 1153 & 32.5 & 23.8 \\
Monaco & 1595 & 28.1 & 25.2 \\
Rome & 1669 & 32.1 & 24.8 \\
Seville & 1851 & 40.4 & 25.2 \\
Cairo & 2209 & 39.7 & 24.7 \\
Phoenix & 2094 & 44.4 & 26.0 \\
Las Vegas & 2032 & 44.4 & 24.4 \\
\hline
\end{tabular}

Solar radiation is important because it is the driving parameter for both the cooling load of the building and the solar cooling system. The dry bulb temperature is important because it represents the inlet air temperature in the HVAC system. The wet bulb temperature is also important because it influences the cooling water temperature at the outlet of the cooling towers. Important differences can be observed between all of the presented parameters.

\subsection{Characteristics of the Solar Cooling System}

The considered fresh air solar cooling system was of the $\mathrm{LiBr}-\mathrm{H}_{2} \mathrm{O}$ absorption type and is presented as an energy flow scheme in Figure 3.

The fresh air cooling system included a HVAC unit, where the fresh air was cooled in a fan and the coil heat exchanger which was supplied with cold water from a $\mathrm{LiBr}-\mathrm{H}_{2} \mathrm{O}$ absorption chiller driven by the hot water provided by the solar thermal system. The effect of a cold water storage tank on the characteristics of the solar cooling system was also evaluated.

The cooling of the absorption chiller was provided by a cooling water circuit, equipped with an adequate water cooling tower.

If the cooling power of the solar driven absorption chiller was not sufficient, the auxiliary electric chiller starts running to complete the required cooling power.

In this study, the electrical energy required for recirculating the chilled water, the hot water, and the cooling water were neglected, being much lower than the electrical energy required to run the compressor of the electric chiller.

The principle scheme of the $\mathrm{LiBr}-\mathrm{H}_{2} \mathrm{O}$ solar absorption chiller is presented in Figure 4. 


\section{Cooling tower}

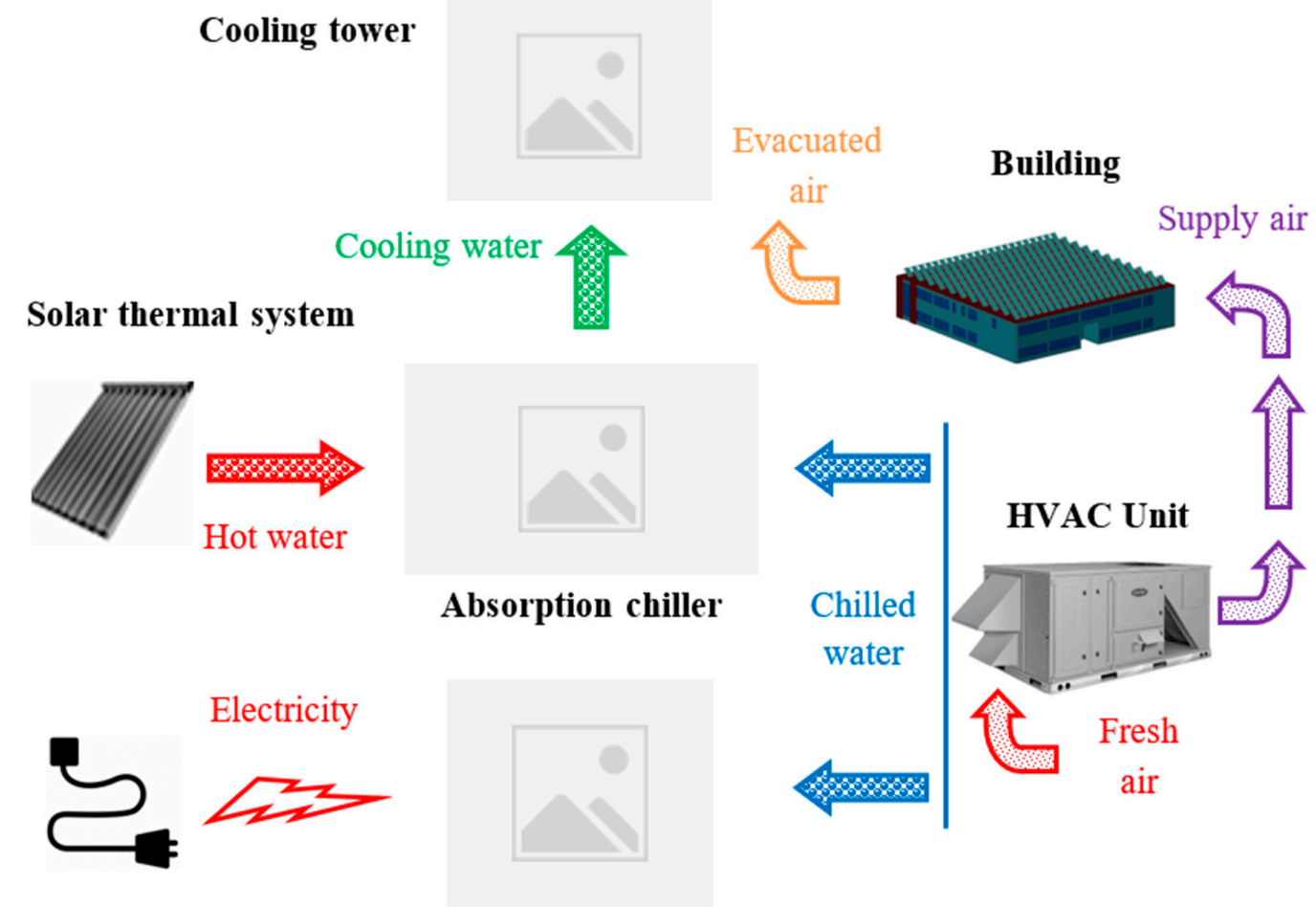

\section{Electrical connection Electric chiller}

Figure 3. Energy flow scheme of a solar absorption fresh air cooling system.

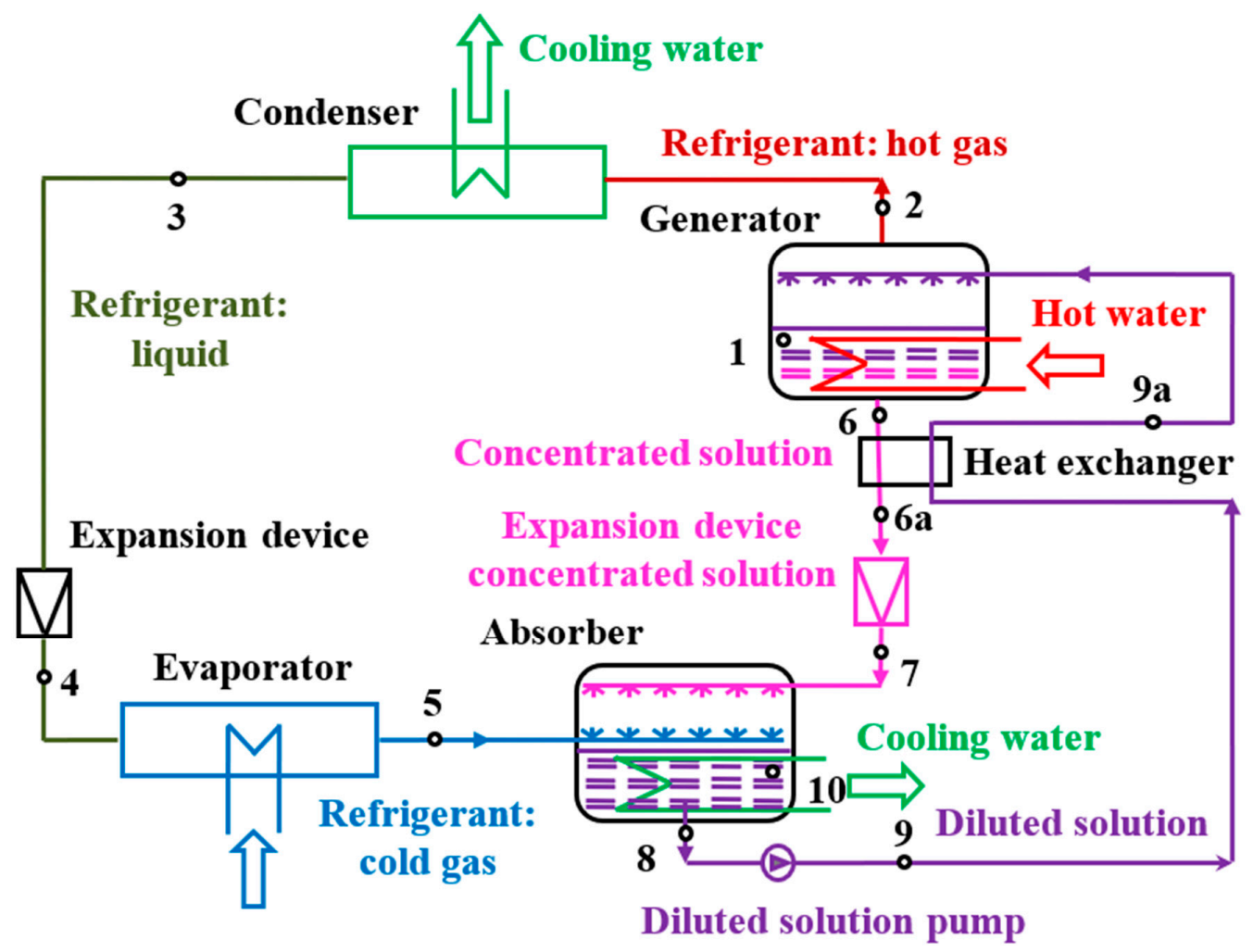

Figure 4. The principle scheme of the $\mathrm{LiBr}-\mathrm{H}_{2} \mathrm{O}$ solar absorption chiller.

The main refrigerating circuit was composed of the condenser, the expansion device, and the evaporator, while the thermochemical compressor was composed of the following components-the 
absorber; the diluted solution pump; the generator; the expansion device of the concentrated solution; and the heat exchanger. The refrigerant of the absorption chiller was $\mathrm{H}_{2} \mathrm{O}$, while $\mathrm{LiBr}$ was the solvent. The working process of the main refrigerating circuit is presented in Figure 5 in the pressure-enthalpy diagram, while the working process of the $\mathrm{LiBr}-\mathrm{H}_{2} \mathrm{O}$ solution is presented in Figure 6 in the enthalpy-concentration diagram.

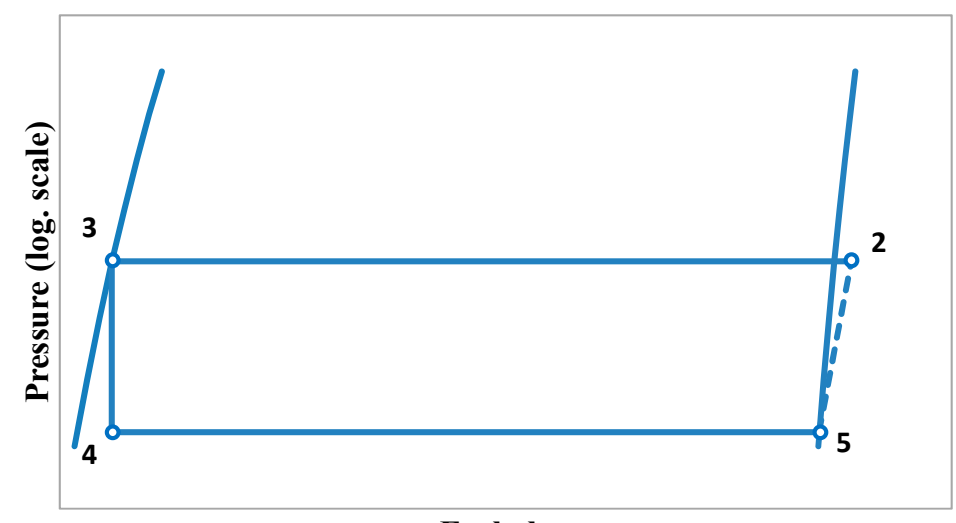

Enthalpy

Figure 5. The working cycle of the main refrigerating circuit.

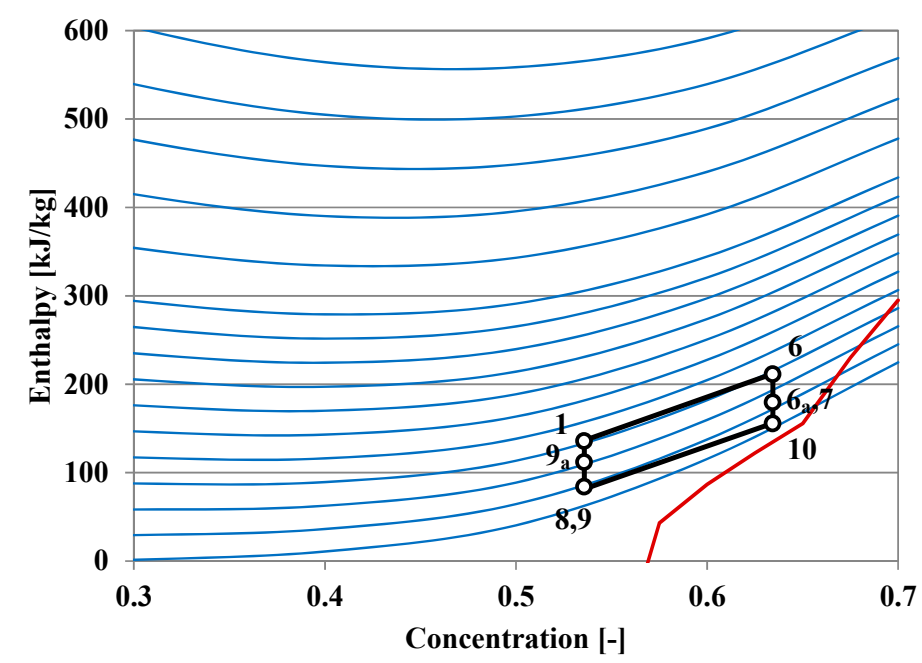

Figure 6. The working cycle of the $\mathrm{LiBr}-\mathrm{H}_{2} \mathrm{O}$ solution.

The red line on the enthalpy-concentration diagram represents the crystallization curve and the working states of the $\mathrm{LiBr}-\mathrm{H}_{2} \mathrm{O}$ solution must always be above this curve. Crystallization was avoided if the temperature in the closest state $\left(t_{10}\left({ }^{\circ} \mathrm{C}\right)\right)$ was higher than the crystallization temperature $\left(t_{c r}\left({ }^{\circ} \mathrm{C}\right)\right)$ :

$$
t_{10}>t_{c r}
$$

The difference between the concentrations of the diluted solution $\left(\zeta_{d}(\%)\right)$ and the concentrated solution $\left(\zeta_{c}(\%)\right)$, representing the degassing zone $\left(\Delta \zeta=\zeta_{d}-\zeta_{c}(\%)\right)$, must be maintained higher than a minimum value $\left(\Delta \zeta_{\min }(\%)\right)$. In this study $\Delta \zeta_{\min }=6 \%$.

The standard thermal regime of the chilled water circuit was identical for both the absorption chiller and electric chiller and was characterized by the flow temperature $\left(t_{f}=7^{\circ} \mathrm{C}\right)$ and return temperature $\left(t_{r}=12^{\circ} \mathrm{C}\right)$. If, due to the operating conditions of the absorption chiller, this thermal regime could not be reached, an alternative chilled water thermal regime of $12-17^{\circ} \mathrm{C}$ was used.

The thermal regime of the cooling water circuit depended on the ambient air temperature and humidity. The flow temperature on the cooling water circuit $\left(t_{f c}\left({ }^{\circ} \mathrm{C}\right)\right)$ was dependent on the wet bulb 
temperature. The return temperature on the cooling water circuit $\left(t_{r c}\left({ }^{\circ} \mathrm{C}\right)\right)$ was controlled to maintain a constant temperature difference $\left(\Delta t_{w c}=t_{r c}-t_{f c}=5^{\circ} \mathrm{C}\right)$.

The thermal regime of the solar hot water was determined by the flow temperature $\left(t_{f h}\left({ }^{\circ} \mathrm{C}\right)\right)$ and return temperature $\left(t_{r h}\left({ }^{\circ} \mathrm{C}\right)\right)$ of the hot water. The flow rate of the hot water circuit was controlled to maintain a temperature difference $\left(\Delta t_{h}=t_{f h}-t_{r h}=5{ }^{\circ} \mathrm{C}\right)$. The hot water parameters must avoid crystallization and must ensure at least the minimum value of the degassing zone.

The internal working conditions were determined as a function of the external working conditions.

The evaporating temperature $\left(t_{0}\left({ }^{\circ} \mathrm{C}\right)\right)$ was determined as a function of the return temperature on the chilled water circuit:

$$
t_{0}=t_{r}-\Delta t_{0}
$$

where $\Delta t_{0}=8^{\circ} \mathrm{C}$.

The condensing temperature $\left(t_{k}\left({ }^{\circ} \mathrm{C}\right)\right)$ was determined as a function of the flow temperature on the cooling water circuit:

$$
t_{k}=t_{f c}-\Delta t_{k}
$$

where $\Delta t_{k}=8^{\circ} \mathrm{C}$.

The diluted solution temperature at the outlet of the absorber $\left(t_{8}\left({ }^{\circ} \mathrm{C}\right)\right)$ was considered equal to the condensing temperature and the temperature at the outlet of the generator $\left(t_{6}\left({ }^{\circ} \mathrm{C}\right)\right)$ was considered lower than the flow temperature of the hot water circuit:

$$
t_{6}=t_{f h}-\Delta t_{g}
$$

where $\Delta t_{g}=10^{\circ} \mathrm{C}$.

The sub-cooling of the diluted solution at the outlet of the heat exchanger was considered $\left(\Delta t_{s}=t_{6}\right.$ $-t_{6 a}=10^{\circ} \mathrm{C}$ ).

The state parameters of the water and the $\mathrm{LiBr}-\mathrm{H}_{2} \mathrm{O}$ solutions (including enthalpy, temperature, pressure, concentration, etc.) together with the thermal power of all of the absorption chiller components were determined using the Engineering Equation Solver (EES) software platform of F-Chart Software, Madison USA.

The mass flow rate on the main refrigerating $(\dot{m}(\mathrm{~kg} / \mathrm{s}))$ circuit was determined as:

$$
\dot{m}=\frac{\dot{Q}}{\left(h_{5}-h_{4}\right)}
$$

The mass flow rates of the diluted solution $\left(\dot{m}_{d}(\mathrm{~kg} / \mathrm{s})\right)$ and the concentrated solution $\left(\dot{m}_{\mathcal{c}}(\mathrm{kg} / \mathrm{s})\right)$ were determined from the mass balance and water balance of the absorber:

$$
\dot{m}_{d}=\dot{m} \frac{\left(1-x_{8}\right)}{\left(x_{8}-x_{7}\right)} ; \dot{m}_{c}=\dot{m}-\dot{m}_{d}
$$

The enthalpy of the diluted solution at the heat exchanger outlet was determined as:

$$
h_{9 a}=\frac{\left(\dot{m}_{c} \cdot\left(h_{6}-h_{6 a}\right)+\dot{m}_{d} \cdot h_{9}\right)}{\dot{m}_{d}}
$$

The thermal power of the condenser $\left(\dot{Q}_{k}(\mathrm{~kW})\right)$ was determined as:

$$
\dot{Q}_{k}=\dot{m} \cdot\left(h_{2}-h_{3}\right)
$$

The thermal power of the absorber $\left(\dot{Q}_{A b}(\mathrm{~kW})\right)$ was determined as:

$$
\dot{Q}_{A b}=\dot{m} \cdot h_{5}+\dot{m}_{c} \cdot h_{7}-\dot{m}_{d} \cdot h_{8}
$$


The thermal power of the generator $\left(\dot{Q}_{G}(\mathrm{~kW})\right)$ was determined as:

$$
\dot{Q}_{G}=\dot{m} \cdot h_{2}+\dot{m}_{c} \cdot h_{6}-\dot{m}_{d} \cdot h_{9 a}
$$

The coefficient of performance (COP (-)) was determined as:

$$
\mathrm{COP}=\frac{\dot{Q}_{0}}{\dot{Q}_{G}}
$$

The mathematical algorithm was implemented in the Engineering Equation Software (EES) that solves coupled non-linear algebraic and differential equations. An important feature of this software platform is the capability to calculate the thermodynamic and transport properties for numerous substances. The mathematical model of the $\mathrm{LiBr}-\mathrm{H}_{2} \mathrm{O}$ absorption chiller was already used and validated in [17]. All the other calculations were implemented in Excel and were carried out on an hourly basis due to the hourly input data of the TMY.

\subsection{Characteristics of the Solar Thermal Collectors}

The hot water that drives the absorption chiller was provided by a solar thermal system. In this study evacuated tubes solar collectors (ETSC) of SolarUK LaZer2 type were considered.

The efficiency of the ETSC $\left(\eta_{t h}(-)\right)$ was determined as [23-25]:

$$
\eta_{t h}=\eta_{0}-a_{1} \frac{t_{a v g}-t_{a}}{I_{g t}}-a_{2} \frac{\left(t_{a v g}-t_{a}\right)^{2}}{I_{g t}}
$$

where $\eta_{0}=0.753$ is the optical efficiency of the collector, while $a_{1}=1.54 \mathrm{~W} / \mathrm{m}^{2} \mathrm{~K}$ and $a_{2}=0.0099 \mathrm{~W} / \mathrm{m}^{2} \mathrm{~K}^{2}$ are coefficients of heat loss. The aperture area of this collector is of $1.864 \mathrm{~m}^{2}$. These values of the ETSC parameters are public, in the test report factsheet of the considered collector, provided by the SPF Institute for Solar Technology.

$t_{\text {avg }}\left({ }^{\circ} \mathrm{C}\right)$ is the average temperature of the hot water in the collectors, $t_{a}\left({ }^{\circ} \mathrm{C}\right)$ is the ambient air temperature, and $I_{g t}\left(\mathrm{~W} / \mathrm{m}^{2}\right)$ is the incident solar radiation on the tilted plane of the ETSC.

In this study, the temperature variation of the hot water in the ETSC was considered to be $20{ }^{\circ} \mathrm{C}$ and the outlet solar hot water temperature was considered dependent on the absorption chiller cooling water temperature.

Figure 7 presents the ETSC thermal efficiency for the two locations.

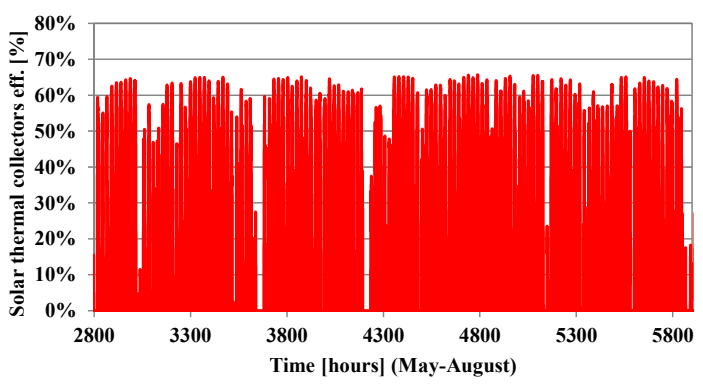

(a) Berlin

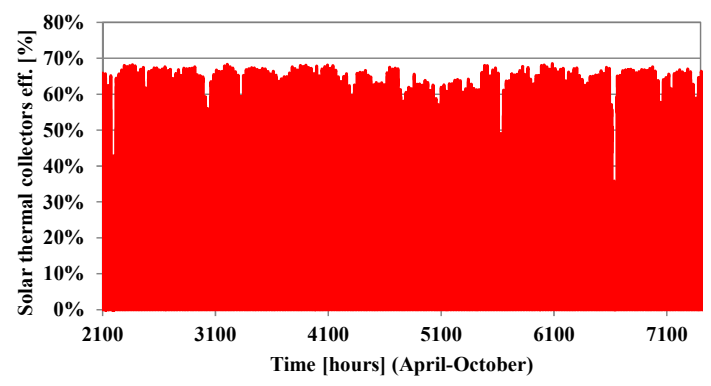

(b) Phoenix

Figure 7. ETSC thermal efficiency for the two locations.

These values were in good agreement with the literature-65\% [15], 60-75\% [26], 78\% [4], 73\% [27], and $45-70 \%$ [28]. 


\section{Results and Discussion}

\subsection{Cooling Load}

Climatic conditions of each location influenced the cooling load of the considered office building. The fresh air volume flow rate $\left(\dot{V}_{a}=7447 \mathrm{~m}^{3} / \mathrm{h}\right)$ was constant during the operating periods and was determined as function of number of occupants and of available floor surface [18].

The fresh air mass flow rate $\left(\dot{m}_{a}(\mathrm{~kg} / \mathrm{s})\right)$ was determined as:

$$
\dot{m}_{a}=\rho_{a} \cdot \dot{V}_{a}
$$

where $\rho_{a}\left(\mathrm{~kg} / \mathrm{m}^{3}\right)$ is the air density variable with temperature and moisture.

The sensible fresh air cooling load $\left(\dot{Q}_{0}(\mathrm{~kW})\right)$ was determined as:

$$
\dot{Q}_{0}=\dot{m}_{a} \cdot c_{a} \cdot\left(t_{a}-t_{s}\right)
$$

where $c_{a}=1 \mathrm{~kJ} / \mathrm{kgK}$ is the specific heat of the air, $t_{a}=t_{d b}\left({ }^{\circ} \mathrm{C}\right)$ is the ambient air (or the dry bulb) temperature, and $t_{s}=22{ }^{\circ} \mathrm{C}$ is the supply air temperature, considered to be constant to provide constant comfort conditions inside the building. It was considered that the inside temperature was also maintained constant $\left(t_{\text {in }}=25^{\circ} \mathrm{C}\right)$ and fresh air cooling was required only when $\left(t_{a}>t_{\text {in }}\right)$.

In the same conditions, the total fresh air cooling load $\left(\dot{Q}_{0 h}[\mathrm{~kW}]\right)$ was determined as:

$$
\dot{Q}_{0 h}=\dot{m}_{a} \cdot\left(h_{a}-h_{s}\right)
$$

where $h_{a}$ and $h_{s}$ are the enthalpies of the ambient air and of the supply air, respectively.

The supply air enthalpy was determined at the considered supply temperature taking into account the two possible cooling cases of ambient air - at a constant humidity ratio or with drying. If the temperature of the heat transfer surface between the chilled water and the air was higher than the dew point of the ambient air, cooling takes place at constant humidity ratio and otherwise with drying. The temperature of the heat transfer surface was $2{ }^{\circ} \mathrm{C}$ higher than the average temperature of the chilled water in the air heat exchanger of the HVAC unit.

The other components of the cooling load in the same office building, situated in different locations are presented in [18] (through the envelope, due to the occupants, due to the lightning, etc).

Table 4 presents the periods in which the fresh air cooling was needed, the maximum sensible cooling load, and the maximum total cooling load, for each location.

Table 4. Periods in which the fresh air cooling is needed and the maximum cooling load.

\begin{tabular}{ccccc}
\hline Location & Beginning Month & Ending Month & $\begin{array}{c}\text { Max. Sensible } \\
\text { Cooling Load (kW) }\end{array}$ & $\begin{array}{c}\text { Max. Total } \\
\text { Cooling Load (kW) }\end{array}$ \\
\hline Berlin & May & August & 31.30 & 37.84 \\
Paris & June & September & 24.68 & 44.00 \\
Monaco & August & August & 14.62 & 33.04 \\
Rome & June & September & 23.89 & 42.29 \\
Seville & April & September & 42.23 & 55.71 \\
Cairo & April & October & 46.31 & 46.64 \\
Phoenix & April & October & 50.75 & 69.09 \\
Las Vegas & April & October & 50.75 & 55.87 \\
\hline
\end{tabular}

The minimum value of the maximum total cooling load corresponded to Monaco and the maximum value of the maximum total cooling load corresponded to Phoenix.

The minimum values of both the maximum sensible cooling load and the maximum total cooling load corresponded to the same location-Monaco, while the maximum values of the same parameters 
corresponded to different locations. The maximum sensible cooling load corresponded to both Phoenix and Las Vegas and the maximum total cooling load corresponded to Phoenix.

Figure 8 presents the cooling load variation for two of the considered locations-Berlin and Phoenix.

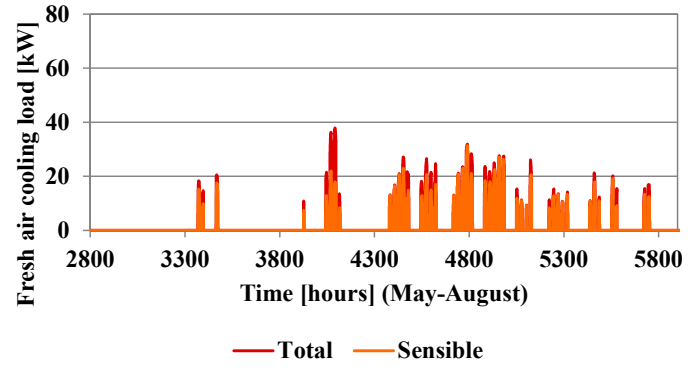

(a) Berlin

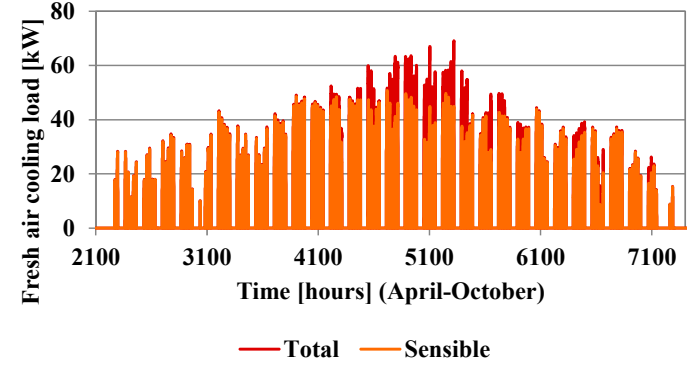

(b) Phoenix

Figure 8. Cooling load variation for two considered locations.

The presented data sustains that the location considerably influenced both the cooling load and the duration of the cooling period. It could also be observed that the points of the maximum sensible and total cooling load did not occur in correspondence.

\subsection{Operating Limits}

The operating limits of the $\mathrm{LiBr}-\mathrm{H}_{2} \mathrm{O}$ absorption chiller were determined by the crystallization risk and the reduction of the degassing zone. The crystallization risk depended on the correlation between both cooling water temperature and hot water temperature. Figure 9 presents the safe zone and the crystallization zone as a function of the two mentioned temperatures for the two thermal regimes of chilled water.

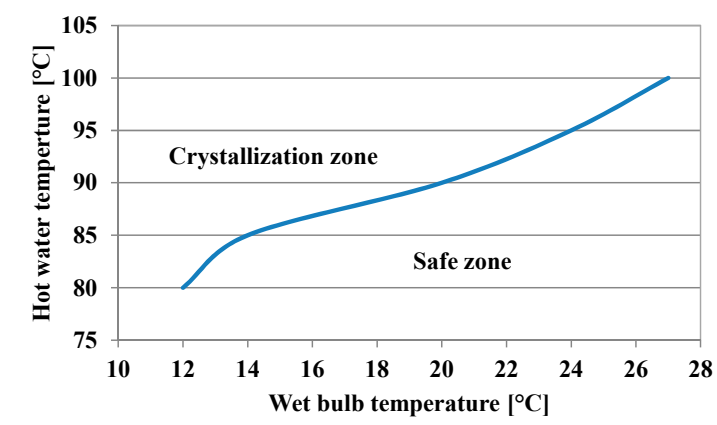

(a) Chilled water thermal regime $(7-12)^{\circ} \mathrm{C}$

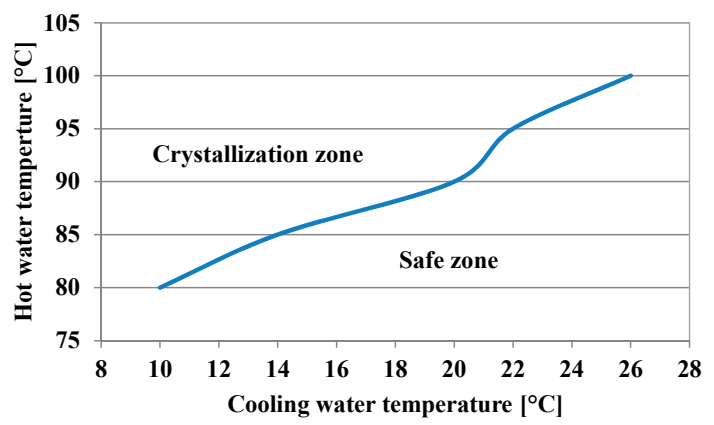

(b) Chilled water thermal regime $(12-17){ }^{\circ} \mathrm{C}$

Figure 9. Safe zone and crystallization zone.

The operating conditions must always be situated below the crystallization curve presented in Figure 8 and it must be correlated with the crystallization curve presented in Figure 6 .

State 10 (Figure 6) was the most critical from the crystallization point of view. The position of state 10 on the enthalpy-concentration diagram was determined at the intersection between the concentration of state $6\left(\zeta_{6}(\%)\right)$ and the evaporating pressure $\left(\mathrm{p}_{0}(\mathrm{bar})\right)$ (similar with the absorption pressure). The concentration of state $6\left(\zeta_{6}\right)$ at its turn, was influenced by the condensing pressure ( $\mathrm{p}_{\mathrm{k}}$ [bar]) (similar with the generator pressure) and the hot water temperature as suggested in Figure 10. 


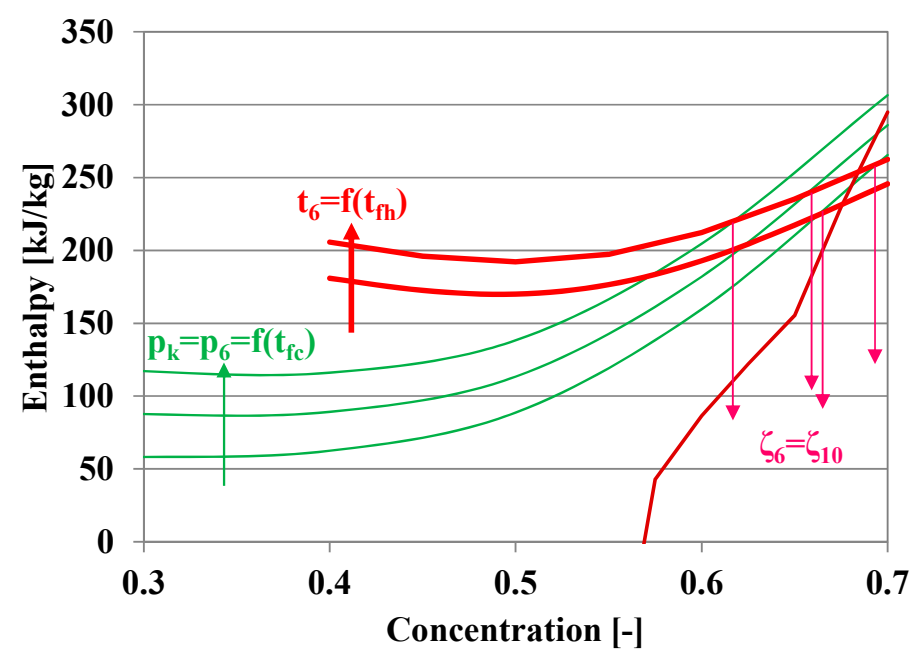

Figure 10. Influence of different parameters on the risk of crystallization.

At a certain value of the condensing pressure (and of the corresponding cooling water temperature), the lower values of the hot water temperature values determined lower values of concentrations, thus reducing the risk of crystallization.

At a certain value of the hot water temperature, the higher values of the condensing pressure (and of the corresponding cooling water temperature) determine lower values of concentrations, thus reducing the risk of crystallization.

It can be concluded that low values of cooling water temperatures (low values of condensing pressure) should be associated with lower values of hot water temperatures to avoid the risk of crystallization. Similarly, high values of cooling water temperatures (high values of condensing pressure) should be associated with higher values of hot water temperatures to avoid the risk of crystallization. This interdependence between the cooling water temperature and the hot water temperature to avoid the risk of crystallization is presented in Figure 9.

The influence of the cooling water temperature on the degassing zone for different hot water temperatures is presented on Figure 11.

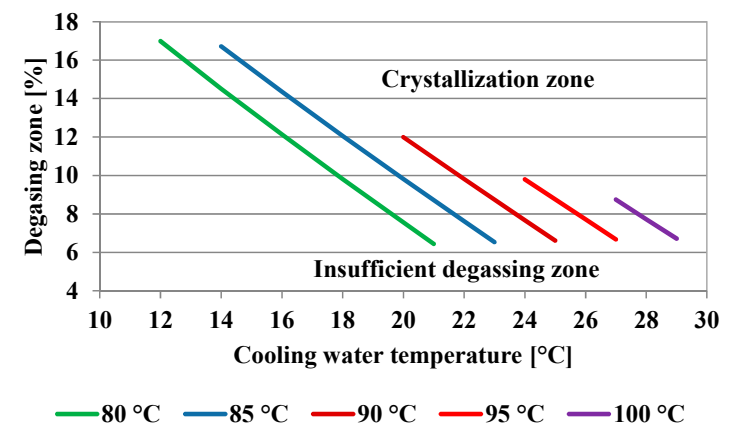

(a) Chilled water thermal regime $(7-12){ }^{\circ} \mathrm{C}$

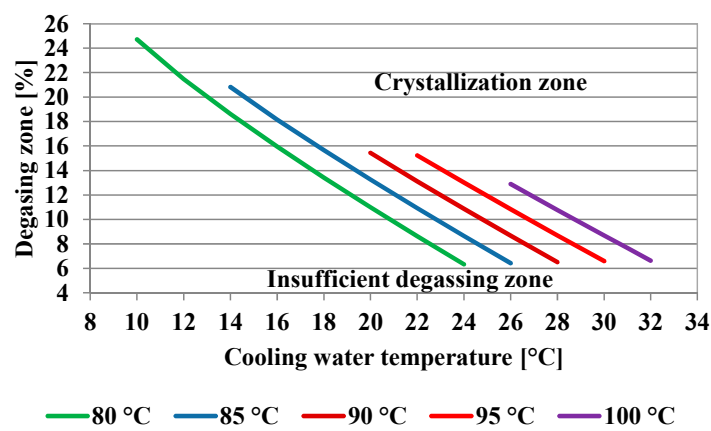

(b) Chilled water thermal regime $(12-17){ }^{\circ} \mathrm{C}$

Figure 11. Influence of the cooling water and hot water temperature on the degassing zone.

The degassing zone decreased with increasing cooling water temperatures (equal with the wet bulb temperature). The upper limits of each line on the chart represent the crystallization limit for each hot water temperature. Each line, corresponding to different hot water temperatures, presents as the left limit-the minimum cooling water temperature that avoids crystallization, and as right limit--the maximum cooling water temperature corresponding to the minimum accepted degassing zone.

Since the concentration of states 10 and $6\left(\zeta_{10}=\zeta_{6}\right)$ was determined as it was presented, the degassing zone was determined by the concentration of states 8 and $1\left(\zeta_{8}=\zeta_{1}\right)$, respectively on 
the concentration of the diluted solution. The influence of the cooling water and the chilled water temperatures on the diluted solution concentration is presented in Figure 12.

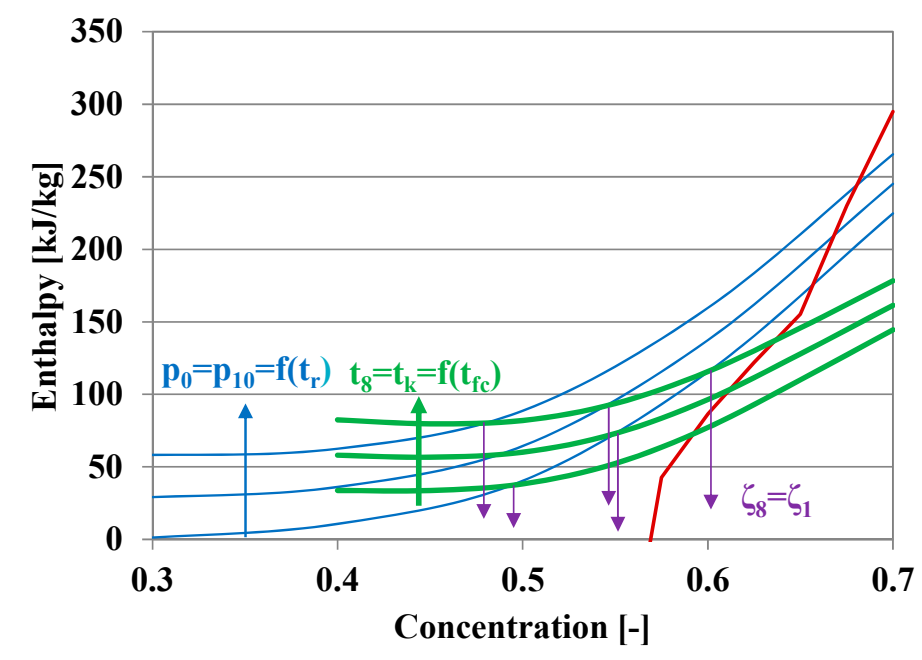

Figure 12. Influence of different parameters on the diluted solution concentration.

At a certain value of evaporating pressure (and of the corresponding chilled water temperature), lower condensing temperature values (and of the corresponding cooling water temperature) determined lower values of the diluted solution concentration and higher values of the degassing zone.

At a certain value of condensing temperature (and of the corresponding cooling water temperature), higher evaporating pressure values (and of the corresponding chilled water temperature) determined lower values of the diluted solution concentration and higher values of the degassing zone.

It can be concluded that if the chilled water temperature and thus the evaporating pressure was constant, and if the hot water temperature was also known (and determined in such a manner as to eliminate the risk of crystallization), then low values of condensing temperature (and of the corresponding cooling water temperature) determines lower values of the diluted solution concentration and higher values of the degassing zone.

Since the operating conditions must satisfy both conditions of no crystallization and sufficient degassing zone, the hot water temperature must be correlated with the cooling water temperature in order to satisfy both restrictions. Thus, at a certain value of the hot water temperature, there exists a lower value of the cooling water temperature limited by the crystallization risk and a higher value of the cooling water temperature limited by the minimum required degassing zone.

It can be observed that the degassing zone decreased with increasing cooling water temperature. The upper limits of each line on the chart represent the crystallization limit for each hot water temperature. Each line, corresponding to different hot water temperatures, presents as the left limit—the minimum cooling water temperature that avoids crystallization, and as the right limit-the maximum cooling water temperature corresponding to the minimum accepted degassing zone.

Figure 13 presents the acceptable operating ranges from the cooling water and hot water temperatures' point of view. 


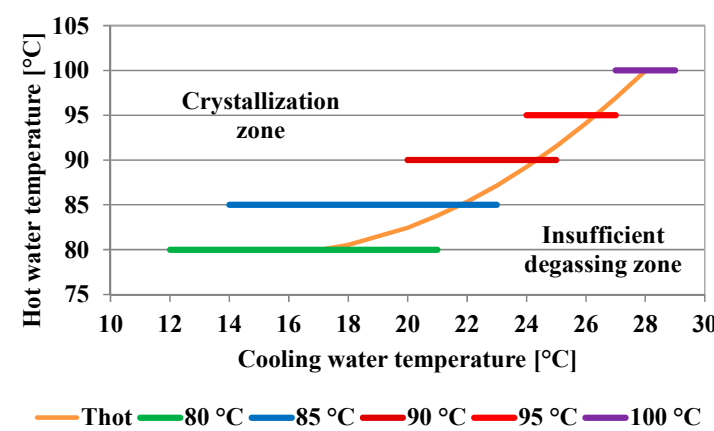

(a) Chilled water thermal regime $(7-12){ }^{\circ} \mathrm{C}$

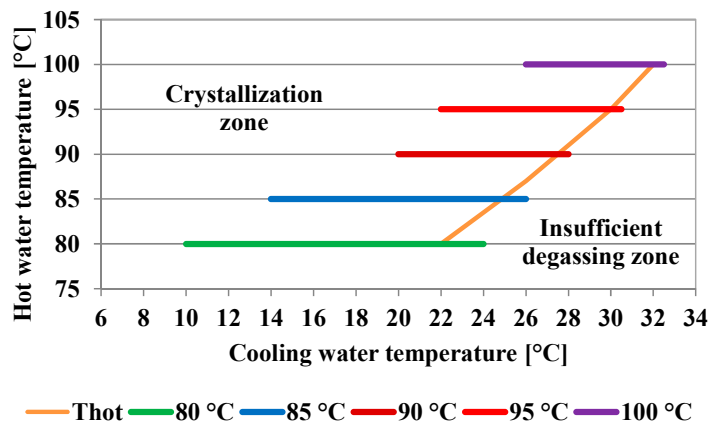

(b) Chilled water thermal regime $(12-17){ }^{\circ} \mathrm{C}$

Figure 13. Acceptable operating ranges.

Since the acceptable operation zone depended on both the hot water and the cooling water temperatures, the dependence between the hot water and the cooling water temperatures was established and represented on the chart. The original correlation for the solar hot water temperature $\left(t_{h}\left({ }^{\circ} \mathrm{C}\right)\right)$ as function of the cooling water temperature $\left(t_{w}\left({ }^{\circ} \mathrm{C}\right)\right)$ to ensure acceptable operating conditions was:

$$
t_{h}=a \cdot t_{w}^{2}-b \cdot t_{w}+c
$$

The coefficients of the hot water temperature correlation are presented in Table 5.

Table 5. The coefficients of the hot water temperature correlation.

\begin{tabular}{ccccc}
\hline Chilled Water & \multicolumn{2}{c}{ Correlation Coefficients } & & $\begin{array}{c}\text { Availability Range } \\
\text { Thermal Regime }\end{array}$ \\
\cline { 2 - 4 } (Cooling Water Thermal Regime)
\end{tabular}

The availability range of this correlation is of $t_{w}=(17-28)^{\circ} \mathrm{C}$. The hot water temperature at the outlet of the solar thermal system should be constant at $80^{\circ} \mathrm{C}$, with the cooling water temperature in the range of $t_{w}=(12-17){ }^{\circ} \mathrm{C}$. If the cooling water temperature at the outlet of the cooling tower decreased below $12{ }^{\circ} \mathrm{C}$ due to the actual operating conditions, the cooling tower must be regulated in order to maintain the outlet cooling water temperature higher than $12^{\circ} \mathrm{C}$.

Figure 14 presents the variation of the cooling water temperature at the outlet of the cooling tower.

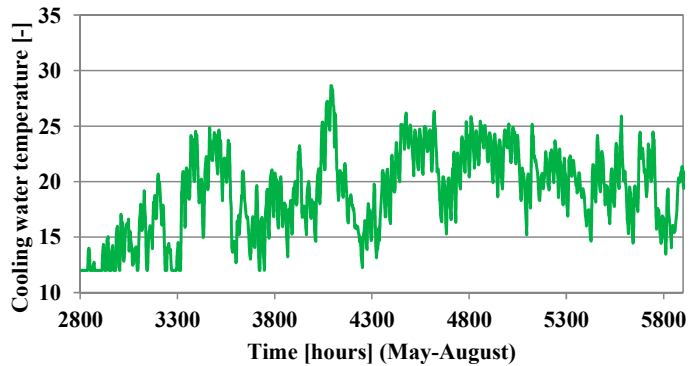

(a) Berlin

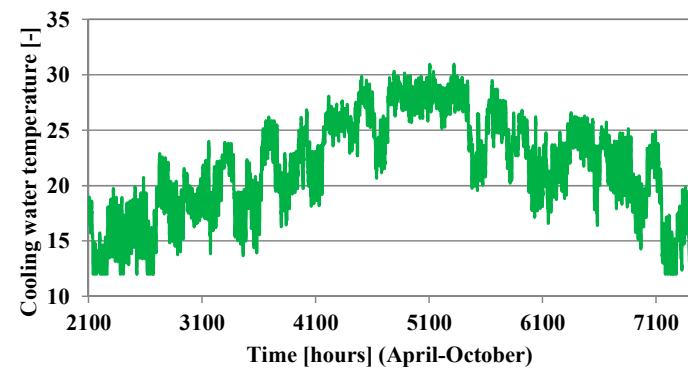

(b) Phoenix

Figure 14. The variation of the cooling water temperature for two locations.

The difference between the cooling water temperature at the outlet of the cooling tower and the wet bulb temperature of the ambient air at the inlet in the cooling towers was $5{ }^{\circ} \mathrm{C}$, which is in agreement with similar values reported in the literature. This parameter was considered in the range 
of (3.2-4.8) ${ }^{\circ} \mathrm{C}$ in [29], and in the range of $(1.5-5.5){ }^{\circ} \mathrm{C}$ in [30]. The wet bulb temperature variation, used to determine the cooling water temperature variations presented in Figure 14, was taken from the TMY as previously mentioned.

Figure 15 presents the variation of the required solar hot water temperature with time, determined by the cooling water temperature variation, for two of the considered locations-Berlin and Phoenix.

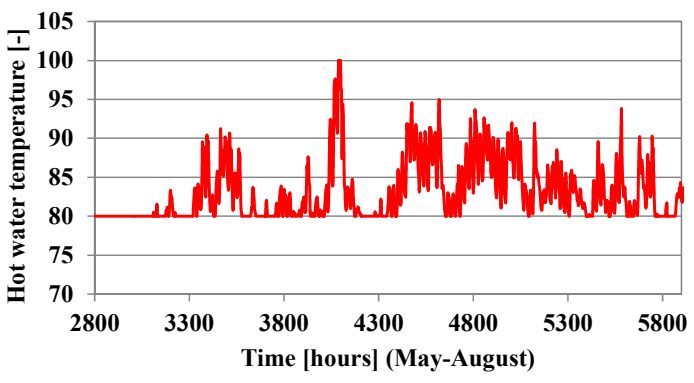

(a) Berlin

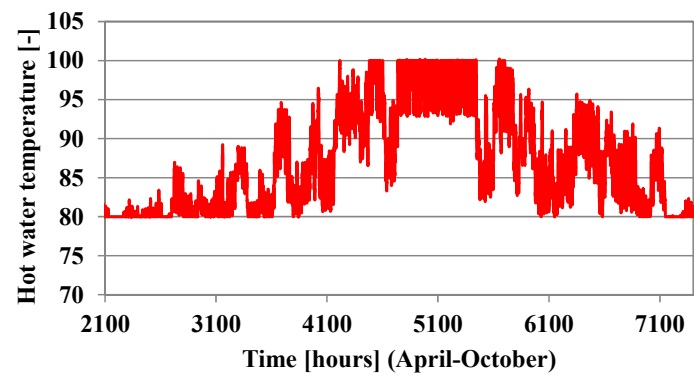

(b) Phoenix

Figure 15. The variation of the required solar hot water temperature for two locations.

The higher values of solar hot water temperature corresponded to the higher values of cooling water temperature. The variations of the solar hot water temperature presented in Figure 15 were determined by using the correlation provided in Equation (16).

The minimum outlet solar hot water temperature is $80^{\circ} \mathrm{C}$ for all locations. The maximum outlet solar hot water temperature is $100^{\circ} \mathrm{C}$ for all locations except for Cairo for which the value is of $96^{\circ} \mathrm{C}$.

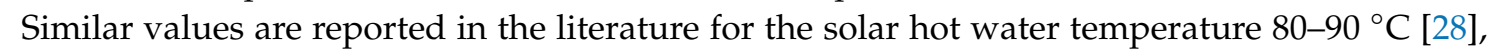
$55-135{ }^{\circ} \mathrm{C}$ [8], $90-100{ }^{\circ} \mathrm{C}$ [15], 85-90 ${ }^{\circ} \mathrm{C}$ [31], and 84-120 ${ }^{\circ} \mathrm{C}$ [14].

\subsection{COP of the Solar Absorption Chiller and of the Electric Chiller}

The COP depends on the thermal regimes of the three connected circuits: cooled water; hot water and cooling water. Since the chilled water thermal regime is constant at $(7-12){ }^{\circ} \mathrm{C}$ or $(12-17){ }^{\circ} \mathrm{C}, \mathrm{COP}$ depends only on the cooling water temperature and on the hot water temperature that at its turn must be correlated with the cooling water temperature.

Figure 16 presents the variation curves of $C O P$ with the cooling water temperature for different hot water temperatures.

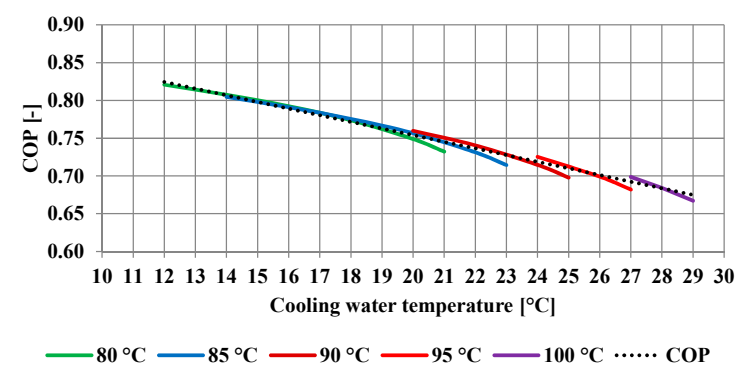

(a) Chilled water $(7-12)^{\circ} \mathrm{C}$

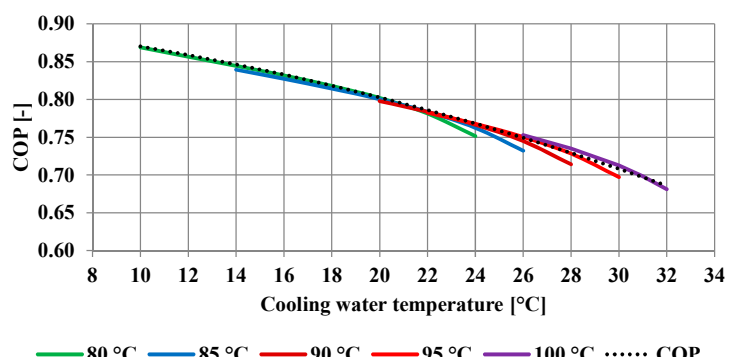

(b) Chilled water $(12-17){ }^{\circ} \mathrm{C}$

Figure 16. Variation of $C O P$ with the cooling water temperature and with hot water temperatures.

For each hot water temperature in the range of $(80-100){ }^{\circ} \mathrm{C}$ the cooling water temperature was considered in the acceptable variation range. The dotted line presents the COP variation with the cooling water temperature. This variation also includes the hot water dependence on the cooling water. 
The correlations for the COP as a function of the cooling water temperature that includes the hot water temperature dependence on the same cooling water temperature $\left(C O P=\mathrm{f}\left(t_{w}, t_{h}\left(t_{w}\right)=\mathrm{f}\left(t_{w}\right)\right)\right.$ was determined as:

$$
\mathrm{COP}=a \cdot t_{w}^{2}+b \cdot t_{w}+c
$$

The coefficients of the COP correlations are presented in Table 6.

Table 6. COP correlation coefficients.

\begin{tabular}{|c|c|c|c|c|}
\hline \multirow{2}{*}{$\begin{array}{l}\text { Chilled Water } \\
\text { Thermal Regime }\end{array}$} & \multicolumn{3}{|c|}{ Correlation Coefficients } & \multirow{2}{*}{$\begin{array}{c}\text { Availability Range } \\
\text { (Cooling Water Thermal Regime) }\end{array}$} \\
\hline & $a$ & $b$ & $c$ & \\
\hline$(7-12)^{\circ} \mathrm{C}$ & 0.0 & -0.0088 & 0.93 & $(17-28)^{\circ} \mathrm{C}$ \\
\hline$(12-17){ }^{\circ} \mathrm{C}$ & -0.000135 & -0.0027 & 0.9107 & $(10-32){ }^{\circ} \mathrm{C}$ \\
\hline
\end{tabular}

Figure 17 presents the COP variation as a function of time, for two of the considered locations: Berlin and Phoenix.

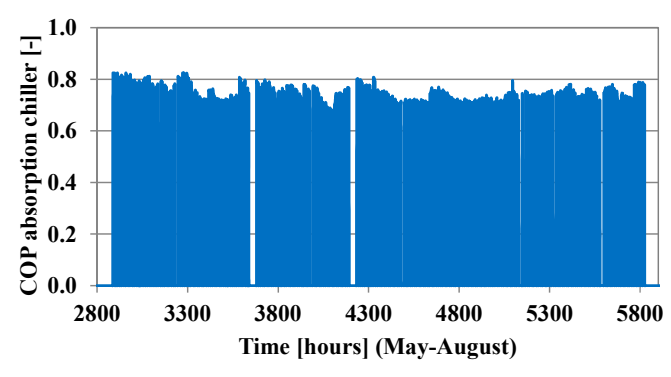

(a) Berlin

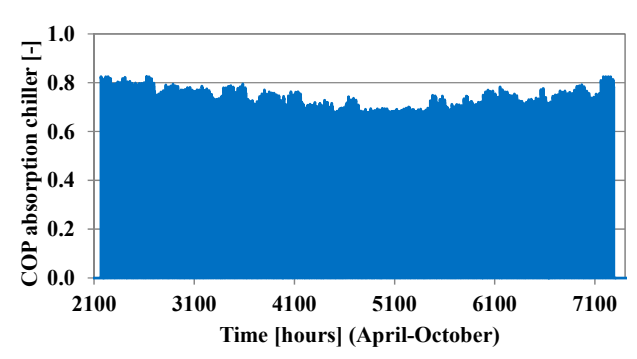

(b) Phoenix

Figure 17. The COP variation for two locations.

The higher values of the COP correspond to the lower values of the cooling water and solar hot water temperatures.

The COP values are in good agreement with the ones reported in the literature: $64-76 \%$ [31], $71-84 \%$ [10], 80\% [8], 40-80\% [9].

The electric power needed to run the electric chiller $\left(P_{e l}(\mathrm{~kW})\right)$ was determined as:

$$
P_{e l}=\frac{\dot{Q}_{0, d e f i c i t}}{C O P_{e l}}
$$

where $\dot{Q}_{0, \text { deficit }}(\mathrm{kW})$ is the difference between the cooling load and the cooling power of the absorption chiller.

The solar fraction (SF (\%)) was defined as the ratio between the cooling power and the cooling load:

$$
S F=\frac{\dot{Q}_{0}}{\dot{Q}_{0 h}}
$$

\subsection{Effect of Chilled Water Storage}

If the SFACS includes a chilled water storage tank (cold storage), several characteristics of the system can be modified: number (or area) of the ETSC; maximum cooling power of the absorption chiller, etc.

In this study, the ETSC field was designed for each location to completely eliminate the electric chiller when chilled water storage is present. The behaviors of the SFACS with the same ETSC field but without storage are also presented. With storage, the absorption chiller can operate and cumulate cold, 
even when fresh air cooling is not needed. The main advantage of the cold storage is the possibility to reduce the maximum cooling power considerably under the cooling load and furthermore the dimensions of the ETSC field.

The problem of sizing the chilled water storage was not approached in this study. It was simply considered that if the cooling power of the SFACS is higher than the cooling load, the exceeding cooling load can be stored as chilled water, to be used when the cooling load exceeds the cooling power.

Figure 18 presents the cooling power and the total cooling load with and without storage in comparison to the cooling load, for two of the considered locations: Berlin and Phoenix.

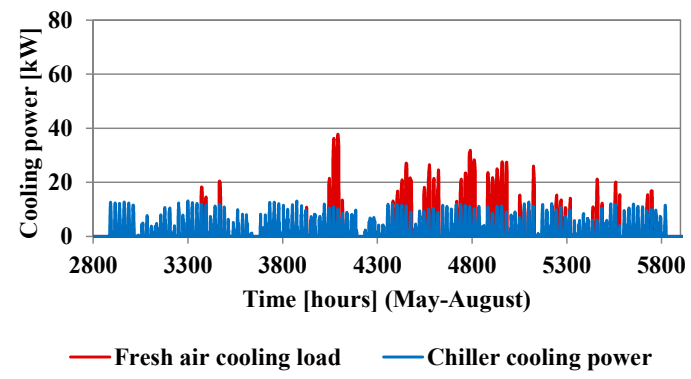

(a) Berlin (with storage)

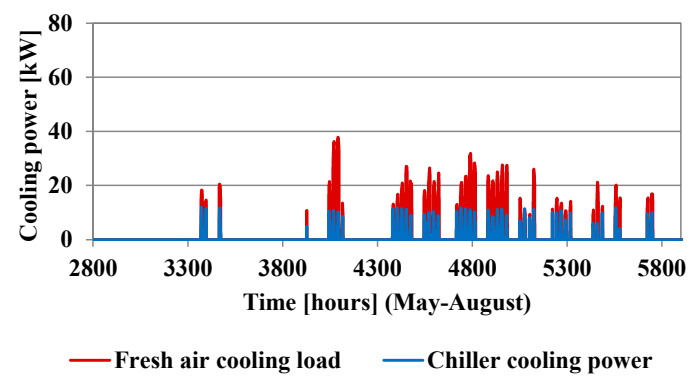

(c) Berlin (without storage)

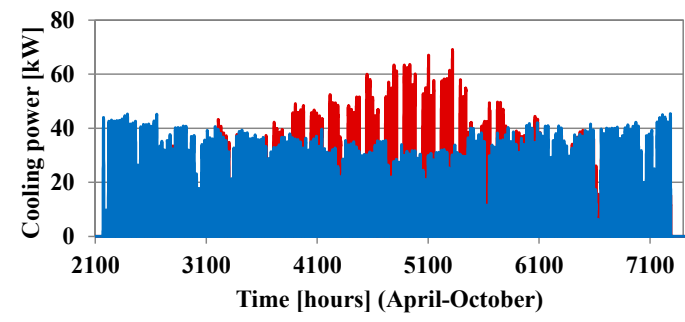

— Fresh air cooling load C Chiller cooling power

(b) Phoenix (with storage)

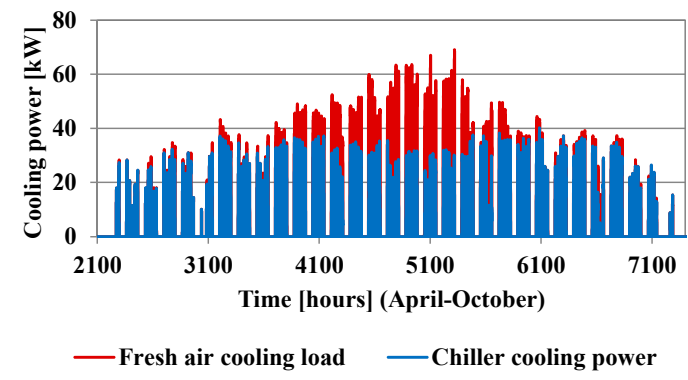

(d) Phoenix (without storage)

Figure 18. The cooling power with and without storage for two locations.

The fresh air cooling loads, presented in Figure 18, were determined based on Equation (15) and the cooling powers, presented in the same Figure, were determined as the product between the COP and the solar heating power (equal with the thermal power of the generator) as stated in Equation (11). At its turn, the COP was determined based on the correlation provided in Equation (17).

Solar cooling with storage was always provided when solar radiation was available, even if the building did not require cooling, as presented in Figure 18a,b. Solar cooling without storage was provided only if the building required cooling and if solar radiation was available, as presented in Figure $18 \mathrm{c}, \mathrm{d}$.

Figure 19 presents the evolution of the stored cold for two of the considered locations-Berlin and Phoenix.

It can be observed that the cold accumulated in periods with a lower cooling load was used in the periods with a high cooling demand in such a manner that there were no periods with a cold deficit. This was the dimensioning criteria for the ETSC field. The number of ETSC for each location is the minimum number that assured no cooling deficit.

When cold was accumulated, the trend of the curves presented in Figure 19 was ascendant, while when the stored cold was used, the trend of the curves presented in Figure 19 was descendent 


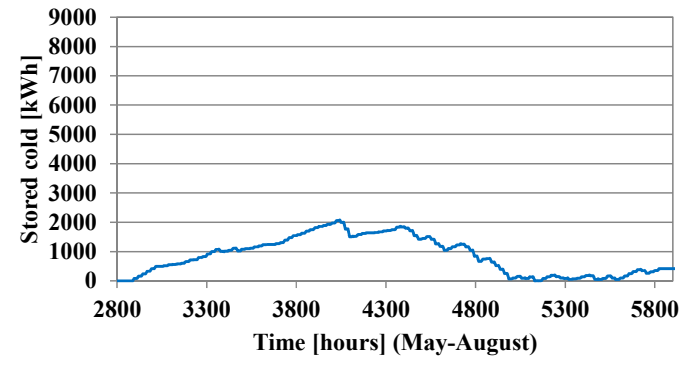

(a) Berlin

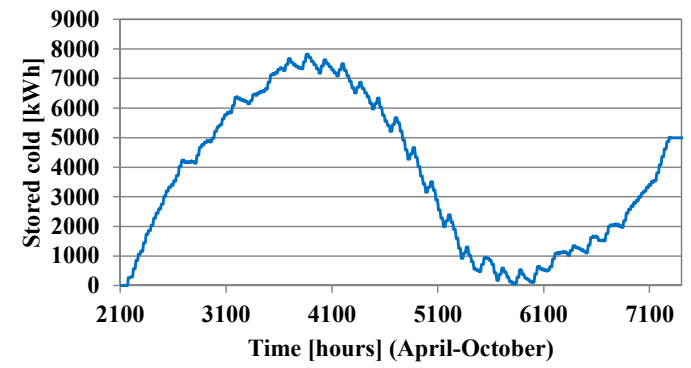

(b) Phoenix

Figure 19. The stored cold.

The produced cooling power was higher in some periods and lower in other periods in comparison to the required cooling load. Using storage, the cold deficit was always avoided, and the seasonal cold balance was such that the SFACS always produced more cooling than required, meaning that the seasonal solar fraction was always higher than $100 \%$.

Figure 20 presents the instantaneous solar fraction without storage, for the two locations.

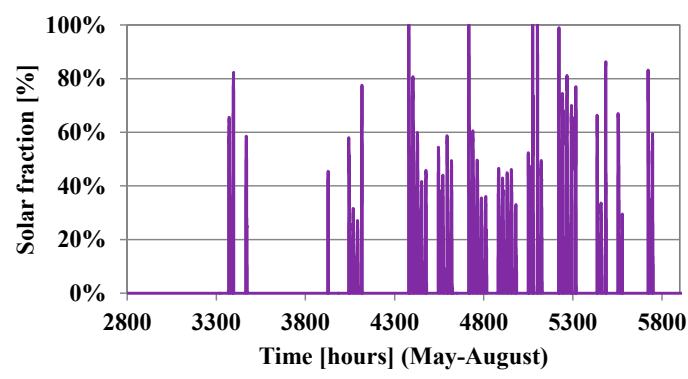

(a) Berlin

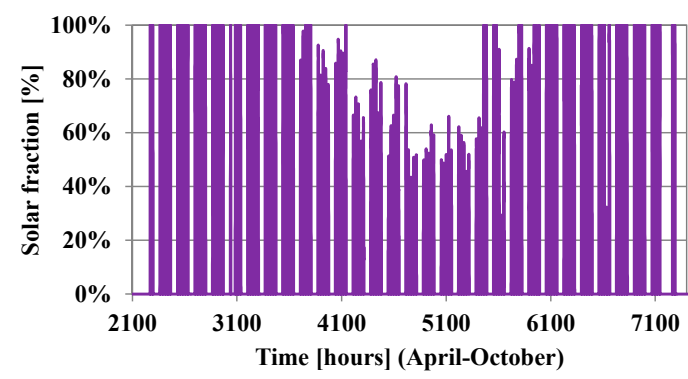

(b) Phoenix

Figure 20. Variation of instantaneous solar fraction without storage.

Since the SFACS are designed to operate with storage and thus with reduced cooling power, without storage the total cooling load could only be completely covered by the absorption chiller (solar fraction a $100 \%$ ) in periods with reduced cooling load and high solar radiation.

The cooling power (chilled water), the solar heating power, and the cooling power of the cooling tower as the main components of the thermal energy balance of the SFACS are presented in Figure 21 for both of the considered locations-Berlin and Phoenix.

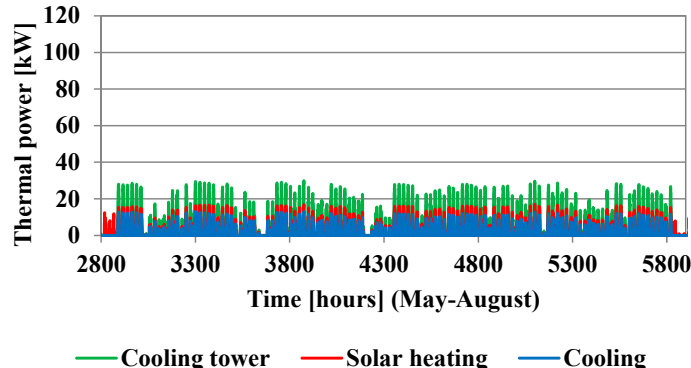

(a) Berlin

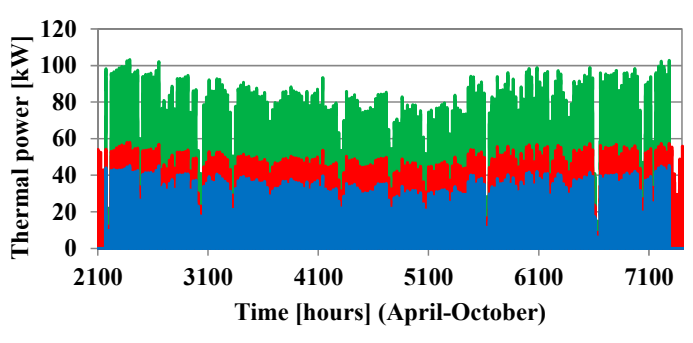

- Cooling tower - Solar heating - Cooling

(b) Phoenix

Figure 21. The main components of the SFACS thermal energy balance.

The thermal energy balance of the SFACS highlight that the sum of the entered thermal powers (the cooling power of the evaporator and the thermal power of the generator) was equal to the sum of the evacuated thermal powers (of the absorber and of the condenser). The thermal power of the 
generator was equal to the solar heating power of the ETSC and the sum between the thermal powers of the absorber and of the condenser represented the thermal power of the cooling tower. Thus, the cooling power of the cooling tower was always equal to the sum between the provided cooling power and the solar heating power, while the cooling power was always lower than the solar heating power, the ratio between the two parameters being the COP.

It can also be observed that the amount of the thermal balance components are about four times higher in Phoenix than the corresponding values in Berlin.

Table 7 presents some characteristics of the SFACS for each location.

Table 7. Characteristics of the SFACS for each location.

\begin{tabular}{|c|c|c|c|c|c|c|c|c|}
\hline Location & Berlin & Paris & Monaco & Rome & Seville & Cairo & Phoenix & Las Vegas \\
\hline No. of ETSC (pcs) & 14 & 12 & 18 & 28 & 30 & 29 & 44 & 32 \\
\hline $\begin{array}{l}\text { Total aperture } \\
\text { surface }\left(\mathrm{m}^{2}\right)\end{array}$ & 26.1 & 22.4 & 33.6 & 52.2 & 55.9 & 54.1 & 82.0 & 59.6 \\
\hline Max. cooling load (kW) & 37.84 & 44.00 & 33.04 & 42.29 & 55.71 & 46.64 & 69.09 & 55.87 \\
\hline $\begin{array}{l}\text { No. of operating hours at } \\
(12-17){ }^{\circ} \mathrm{C} \text { chilled water }(\mathrm{h})\end{array}$ & 0 & 0 & 121 & 25 & 32 & 0 & 157 & 4 \\
\hline $\begin{array}{c}\text { Max. absorption } \\
\text { cooling power } \\
\text { (with storage) (kW) }\end{array}$ & 13.15 & 10.75 & 14.70 & 23.89 & 26.86 & 30.26 & 45.29 & 33.48 \\
\hline $\begin{array}{c}\text { Max. absorption } \\
\text { cooling power } \\
\text { (without storage) }(\mathrm{kW})\end{array}$ & 11.99 & 10.40 & 14.41 & 22.36 & 26.46 & 29.62 & 40.06 & 30.86 \\
\hline $\begin{array}{c}\text { Electrical power } \\
\text { (with storage) }(\mathrm{kW})\end{array}$ & 0.0 & 0.0 & 0.0 & 0.0 & 0.0 & 0.0 & 0.0 & 0.0 \\
\hline $\begin{array}{l}\text { Max. electrical power } \\
\text { (without storage) (kW) }\end{array}$ & 9.10 & 11.58 & 9.56 & 10.14 & 12.72 & 6.73 & 18.04 & 13.67 \\
\hline $\begin{array}{l}\text { Total cooling load } \\
\text { (seasonal) (MWh) }\end{array}$ & 6.14 & 2.56 & 2.09 & 12.74 & 24.18 & 31.79 & 41.90 & 31.07 \\
\hline $\begin{array}{l}\text { Seasonal solar fraction } \\
\text { (with storage) }(\%)\end{array}$ & $106.8 \%$ & $176.9 \%$ & $114.4 \%$ & $121.0 \%$ & $102.9 \%$ & $109.9 \%$ & $111.9 \%$ & $115.8 \%$ \\
\hline $\begin{array}{l}\text { Seasonal solar fraction } \\
\text { (without storage) }(\%)\end{array}$ & $35.7 \%$ & $29.5 \%$ & $35.3 \%$ & $57.2 \%$ & $52.4 \%$ & $57.4 \%$ & $62.0 \%$ & $53.9 \%$ \\
\hline $\begin{array}{l}\text { Seasonal electric fraction } \\
\text { (without storage) (\%) }\end{array}$ & $64.3 \%$ & $70.5 \%$ & $64.7 \%$ & $42.8 \%$ & $47.6 \%$ & $42.6 \%$ & $38.0 \%$ & $46.1 \%$ \\
\hline $\begin{array}{l}\text { Total electrical energy } \\
\text { (with storage) (kWh) }\end{array}$ & 0.0 & 0.0 & 0.0 & 0.0 & 0.0 & 0.0 & 0.0 & 0.0 \\
\hline $\begin{array}{c}\text { Total electrical energy } \\
\text { (without storage) (kWh) }\end{array}$ & 955.7 & 465.0 & 382.3 & 1455.0 & 1048.2 & 2261.6 & 4192.3 & 3431.8 \\
\hline $\begin{array}{l}\text { Seasonal energy efficiency } \\
\text { ratio (electric) (SEERel) (-) }\end{array}$ & 4.1 & 3.9 & 3.5 & 3.7 & 3.8 & 6.0 & 3.8 & 4.2 \\
\hline $\begin{array}{l}\text { Seasonal energy efficiency } \\
\text { ratio (global) (SEERgl) (-) }\end{array}$ & 6.4 & 5.5 & 5.5 & 8.8 & 8.8 & 14.1 & 10.0 & 9.1 \\
\hline
\end{tabular}

Several observations can be made by analyzing the comparative data concerning the SFACS.

The climate type was not sufficient to provide a guideline concerning the SFACS. Calculations were always needed and should be based on the particular local climate or meteorological data. In this study the TMY data was used. For example, locations with similar climate types (Cairo and Phoenix) were characterized by a different maximum cooling load (46.64 kW and $69.09 \mathrm{~kW}$, respectively), by a different maximum cooling power of the absorption chiller in both operating situations-(with cold storage $30.26 \mathrm{~kW}$ and $45.29 \mathrm{~kW}$, respectively) or (without cold storage $29.62 \mathrm{~kW}$ and $40.06 \mathrm{~kW}$, respectively), and by a different number of ETCS ( 29 and 44, respectively), etc. As another example, even if situated in different climate zones, the characteristics of the SFACS in Seville and Cairo were 
almost similar. Another comparison can be carried out between Seville and Cairo. In Seville the number of ECTS (30) was higher than Cairo (29), but the provided cooling power with and without storage was lower than Cairo ( $26.86 \mathrm{~kW}$ vs. $30.26 \mathrm{~kW}$ with storage and $26.46 \mathrm{~kW}$ vs. $29.62 \mathrm{~kW}$ without storage).

The major benefit of using the cold storage tank was that on one hand it could reduce the required cooling power and furthermore the size of ECTS field, and on the another hand, it did not require the electric chiller and its electrical energy consumption.

It can be observed that the values of the maximum absorption cooling power with storage were higher than the values of the maximum absorption cooling power without storage for all of the considered locations. This occurs due to the fact that with storage there were more operating periods than without storage and if the number of operating periods increased then the chance to reach more favorable operating conditions also increased, with high solar radiation and high COP.

Without cold storage, the SFACS couldn't provide enough cooling power to cover the whole cooling demand. Thus, when the cooping power provided by the SFACS was insufficient, the operation of the electric chiller was required.

Depending on the local meteorological conditions, the characteristics of the SFACS varies considerably:

- $\quad$ The number of ETCS varied from 12 in Paris up to 44 in Phoenix and the corresponding total aperture area varied from $22.4 \mathrm{~m}^{2}$ in Paris to $82.0 \mathrm{~m}^{2}$ in Phoenix;

- The total seasonal cooling load represents the total required cooling energy. This parameter was calculated hourly as the product between the cooling load (thermal power) and the period of time when cold was required. The sum of the hourly required cooling energy represents the total seasonal cooling load and varied between 2.09 MWh in Monaco up to 41.90 MWh in Phoenix.

- The cooling power of the absorption chiller with cooling storage varied from $10.75 \mathrm{~kW}$ in Paris up to $45.29 \mathrm{~kW}$ in Phoenix;

- $\quad$ The cooling power of the absorption chiller without cooling storage varied from $10.40 \mathrm{~kW}$ in Paris up to $40.06 \mathrm{~kW}$ in Phoenix;

- $\quad$ The cooling storage proved to be capable of covering the cooling load without the electric chiller and the corresponding electrical energy consumption;

- The maximum required electric power of the electric chiller, without storage varied between $6.73 \mathrm{~kW}$ in Cairo up to $18.04 \mathrm{~kW}$ in Phoenix;

- The seasonal solar fraction with storage was higher than $100 \%$, meaning that with storage more cold could be produced than required for the fresh air cooling, the extra cold production being, possibly, used to cover other types of cooling loads inside the building (through envelope, from occupants, from lighting, etc.);

- The seasonal solar fraction without storage varied between $29.5 \%$ in Paris up to $62.0 \%$ in Phoenix;

- The total amount of electrical energy required without storage was situated in the range of $382.3 \mathrm{~kW}$ (Monaco) up to $4192.3 \mathrm{~kW}$ (Phoenix);

- $\quad$ The seasonal energy efficiency ratio (SEER) represents the ratio between the seasonal provided cold and the total required seasonal electrical energy. Two types of SEER were defined-(a) the electrical seasonal energy efficiency ratio (SEERel) calculated considering only the electrical provided cold; and (b) the global seasonal energy efficiency ratio (SEERgl) considering the whole amount of provided cold (solar + electric). SEERel was between 3.5 in Monaco and 6.0 in Cairo. SEERgl was between 5.5 in Paris or Monaco and 14.1 in Cairo.

\section{Conclusions}

The study presents a new perspective to the SFACS serving an office building placed in different climatic conditions, carried out by simulation. The complete analytical mathematical model of the SFACS thermal behavior was presented in detail. The presented results refer to both operating conditions and parameters of performance. 
The standard thermal regime of the chilled water circuit in the absorption chiller was (7-12) ${ }^{\circ} \mathrm{C}$, similar to that of classical electric chillers. If the operating conditions of the absorption chiller became incompatible with this thermal regime, an alternative chilled water thermal regime of $(12-17){ }^{\circ} \mathrm{C}$ was proposed. In Berlin, Paris, and Cairo the operating conditions always allowed the chilled water to operate at the thermal regime of $(7-12){ }^{\circ} \mathrm{C}$. In Las Vegas the chilled water thermal regime of $(12-17){ }^{\circ} \mathrm{C}$ was needed for only $4 \mathrm{~h}$, while this thermal regime was required for $25 \mathrm{~h}$ in Rome, $32 \mathrm{~h}$ in Seville, $121 \mathrm{~h}$ in Monaco, and $157 \mathrm{~h}$ in Phoenix.

New correlations between the solar hot water temperature and the cooling water temperature were proposed for two thermal regimes of the chilled water, in order to avoid both crystallization and the reduction of the degassing zone below $6 \%$.

New correlations between the COP variation of the $\mathrm{LiBr}-\mathrm{H}_{2} \mathrm{O}$ absorption chiller and the cooling water temperature were proposed for two thermal regimes of the chilled water. These variations also embed the solar hot water temperature variation as a function of the same cooling water temperature.

Based on the SFACS mathematical model, its thermal behavior was simulated considering the system located in different locations with different climatic conditions.

It was highlighted that the local climatic particularities determined very different characteristics of the SFACS:

The maximum cooling load varied between $33.04 \mathrm{~kW}$ in Monaco to $69.09 \mathrm{~kW}$ in Phoenix;

The number of ETSC varied from 12 in Paris to 44 in Phoenix;

The maximum values of the $\mathrm{LiBr}-\mathrm{H}_{2} \mathrm{O}$ absorption chiller $\mathrm{COP}$, varied from $76.5 \%$ for Monaco and $79.3 \%$ for Rome to $82.4 \%$ for the rest of considered locations.

It was found that using a cold storage tank affected many characteristics of the SFACS:

The seasonal electrical energy consumption for fresh air cooling could be reduced up to $0 \mathrm{kWh}$;

The need of using a peek load electrical chiller could be eliminated, and the solar fraction of the fresh air cooling load could be increased from (29.5-62.0)\% without cold storage (depending on the location) to more than $100 \%$ and the exceeding cold could be used to partially cover other types of cooling loads of the building - through the envelope, from the lighting system, and from occupants, etc.

Future work can be focused on the limits and performances of air cooled SFACS, on the dimensioning of the storage tank, and on the SFACS optimization depending on the storage tank volume.

Author Contributions: A.C.A. designed the study and wrote the initial draft of the manuscript. O.G.P. analyzed and validated the data and the results. A.S. designed the methodology and realized the data validation. M.C.B. realized the computing programs and was responsible with the analysis and interpretation of the data. All authors approved the final version of the manuscript.

Funding: This research received no external funding.

Conflicts of Interest: The authors declare no conflicts of interest.

\section{References}

1. Directive/31/EU, Directive 2010/31/EU of the European Parliament and of the Council of 19 May 2010 on the Energy Performance of Buildings in 2010. Available online: https://www.google.com.tw/url?sa=t\&rct=j\&q=\&esrc=s\& source $=$ web\&cd $=1 \& c a d=$ rja\&uact $=8 \& v e d=2$ ahUKEwi3mvHtsMriAhUVPnAKHYpUDAAQFjAAegQIBhAC\& url=https \%3A \%2F\%2Feur-lex.europa.eu\%2FLexUriServ\%2FLexUriServ.do\%3Furi\%3DOJ\%3AL\%3A2010\% 3A153\%3A0013\%3A0035\%3AEN\%3APDF\&usg=AOvVaw0pOZGXaqo5VZyusosxfeop (accessed on 7 April 2019).

2. Wei, Y.; Zhang, X.; Shi, Y.; Xia, L.; Pan, S.; Wu, J.; Han, M. A review of data-driven approaches for prediction and classification of building energy consumption. Renew. Sustain. Energy Rev. 2018, 82, 1027-1047. [CrossRef]

3. Roaf, S.; Brotas, L.; Nicol, F. Counting the costs of comfort. Build. Res. Inf. 2015, 43, 269-273. [CrossRef]

4. Mammoli, A.; Vorobieff, P.; Barsun, H.; Burnett, R.; Fisher, D. Energetic, economic and environmental performance of a solar-thermal-assisted HVAC system. Energy Build. 2010, 42, 1524-1535. [CrossRef]

5. Wang, J.; Yan, R.; Wang, Z.; Zhang, X.; Shi, G. Thermal Performance Analysis of an Absorption Cooling System Based on Parabolic Trough Solar Collectors. Energies 2018, 11, 2679. [CrossRef] 
6. Ma, Y.; Saha, S.C.; Miller, W.; Guan, L. Comparison of Different Solar-Assisted Air Conditioning Systems for Australian Office Buildings. Energies 2017, 10, 1463. [CrossRef]

7. Chan, J.J.; Best, R.; Cerezo, J.; Barrera, M.A.; Lezama, F.R. Experimental Study of a Bubble Mode Absorption with an Inner Vapor Distributor in a Plate Heat Exchanger-Type Absorber with NH3-LiNO. Energies 2018, 11, 2137. [CrossRef]

8. Cerezo, J.; Romero, R.J.; Ibarra, J.; Rodríguez, A. Dynamic Simulation of an Absorption Cooling System with Different Working Mixtures. Energies 2018, 12, 259. [CrossRef]

9. Sarbu, I.; Sebarchievici, C. Review of solar refrigeration and cooling systems. Energy Build. 2013, 67, $286-297$. [CrossRef]

10. Manu, S.; Chandrashekar, T.K. A simulation study on performance evaluation of single-stage $\mathrm{LiBr}-\mathrm{H}_{2} \mathrm{O}$ vapor absorption heat pump for chip cooling. Int. J. Sustain. Built Environ. 2016, 5, 370-386. [CrossRef]

11. Patel, H.A.; Patel, L.N.; Jani, D.; Christian, A. Energetic analysis of single stage lithium bromide water absorption refrigeration system. Procedia Technol. 2016, 23, 488-495. [CrossRef]

12. Farnós, J.; Papakokkinos, G.; Castro, J.; Morales, S.; Oliva, A. Dynamic Modelling of an Air-Cooled $\mathrm{LiBr}-\mathrm{H}_{2} \mathrm{O}$ Absorption Chiller Based on Heat and Mass Transfer Empirical Correlations. Available online: https:/www.google.com.tw/url?sa=t\&rct=j\&q=\&esrc=s\&source=web\&cd=1\&ved=2ahUKEwirvLucscriAhUN2EKHRJ7B8EQFjAAegQIBhAC\&url=https\%3A\%2F\%2Fhpc2017.org\%2Fwp-content $\% 2$ Fuploads\%2F2017\% 2F06\%2Fo454.pdf\&usg=AOvVaw1CSUoj6w0EocuFqv91wyTW (accessed on 7 April 2019).

13. Stanciu, C.; Stanciu, D.; Gheorghian, A.T.; Tanase, E.B.; Dobre, C.; Spiroiu, M. Maximum Exergetic Efficiency Operation of a Solar Powered $\mathrm{H}_{2} \mathrm{O}-\mathrm{LiBr}$ Absorption Cooling System. Entropy 2017, 19, 676. [CrossRef]

14. Lizarte, R.; Izquierdo, M.; Marcosc, J.D.; Palacios, E. Experimental comparson of two solar-driven air-cooled $\mathrm{LiBr} / \mathrm{H}_{2} \mathrm{O}$ absorption chillers: Indirect versus direct air-cooled system. Energy Build. 2013, 62, 323-334. [CrossRef]

15. Chen, J.F.; Dai, Y.J.; Wang, R.Z. Experimental and analytical study on an air-cooled single effect $\mathrm{LiBr}-\mathrm{H}_{2} \mathrm{O}$ absorption chiller driven by evacuated glass tube solar collector for cooling application in residential buildings. Sol. Energy 2017, 151, 110-118. [CrossRef]

16. Salehi, S.; Yari, M.; Mahmoudi, S.M.S.; Farshi, L.G. Investigation of crystallization risk in different types of absorption $\mathrm{LiBr} / \mathrm{H}_{2} \mathrm{O}$ heat transformers. Ther. Sci. Eng. Prog. 2019, 10, 48-58. [CrossRef]

17. Porumb, R.; Porumb, B.; Balan, M.C. Numerical investigation on solar absorption chiller with $\mathrm{LiBr}-\mathrm{H}_{2} \mathrm{O}$ operating conditions and performances. Energy Procedia 2017, 112, 108-117. [CrossRef]

18. Pop, O.G.; Fechete Tutunaru, L.; Bode, F.; Abrudan, A.C.; Balan, M.C. Energy efficiency of PCM integrated in fresh air cooling systems in different climatic conditions. Appl. Energy 2018, 212, 976-996. [CrossRef]

19. Todoran, T.P.; Balan, M.C. Long term behavior of a geothermal heat pump with oversized horizontal collector. Energy Build. 2016, 133, 799-809. [CrossRef]

20. Porumb, B.; Balan, M.C.; Porumb, R. Potential of indirect evaporative cooling to reduce the energy consumption in fresh air conditioning applications. Energy Procedia 2016, 85, 433-441. [CrossRef]

21. Badescu, V.; Laaser, N.; Crutescu, R. Warm season cooling requirements for passive buildings in Southeastern Europe (Romania). Energy 2010, 35, 3284-3300. [CrossRef]

22. Badescu, V.; Laaser, N.; Crutescu, R.; Crutescu, M.; Dobrovicescu, A.; Tsatsaronis, G. Modeling, validation and time-dependent simulation of the first large passive building in Romania. Renew. Energy 2011, 36, 142-157. [CrossRef]

23. Duffie, J.A.; Beckman, W.A. Solar Engineering of Thermal Processes; Wiley\&Sons: Singapore, 1980.

24. Quaschning, V. Understanding Renewable Energy Systems; Earthscan: London, UK, 2007.

25. Unguresan, P.V.; Porumb, R.A.; Petreus, D.; Pocola, A.G.; Pop, O.G.; Balan, M.C. Orientation of Facades for Active Solar Energy Applications in Different Climatic Conditions. J. Energy Eng. 2017, 143, 04017059. [CrossRef]

26. Prieto, A.; Knaack, U.; Auer, T.; Klein, T. Feasibility Study of Self-Sufficient Solar Cooling Façade Applications in Different Warm Regions. Energies 2018, 11, 1475. [CrossRef]

27. Unguresan, P.; Petreus, D.; Pocola, A.; Balan, M. Potential of solar ORC and PV systems to provide electricity under Romanian climatic conditions. Energy Procedia 2016, 85, 584-593. [CrossRef]

28. Porumb, R.; Porumb, B.; Balan, M. Baseline evaluation of potential to use solar radiation in air conditioning applications. Energy Procedia 2016, 85, 442-451. [CrossRef] 
29. Syed, A.; Izquierdo, M.; Rodriguez, P.; Maidment, G.; Missenden, J. A novel experimental investigation of a solar cooling system in Madrid. Int J. Refrig. 2005, 28, 859-871. [CrossRef]

30. Stanford, H.W., III. HVAC Water Chillers and Cooling Towers. Fundamentals, Application, and Operation; Marcel Dekker: New York, NY, USA, 2003.

31. Chen, J.F.; Dai, Y.J.; Wang, H.B.; Wang, R.Z. Experimental investigation on a novel air-cooled single effect $\mathrm{LiBr}-\mathrm{H}_{2} \mathrm{O}$ absorption chiller with adiabatic flash evaporator and adiabatic absorber for residential application. Sol. Energy 2018, 159, 579-587. [CrossRef]

(C) 2019 by the authors. Licensee MDPI, Basel, Switzerland. This article is an open access article distributed under the terms and conditions of the Creative Commons Attribution (CC BY) license (http://creativecommons.org/licenses/by/4.0/). 